\title{
Some Pennsylvanian arborescent lycopsid cones and their microspores from the British coalfields
}

\author{
STANISLAV OPLUŠTIL \& JIŘÍ BEK
}

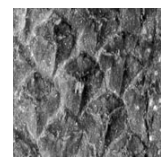

\begin{abstract}
Six fructifications of arborescent lycopsids and their in situ spores from the Westphalian Coal Measures of the Pennine Basin and the Clackmannan Coalfield in Scotland, UK, were studied to improve our knowledge of their taxonomic characteristics and to provide a basis for the comparison of the floras of the British and Czech coalfields. The cones, which yielded in situ spores, were assigned to the genera Lepidostrobus (Brongniart) Brack-Hanes \& Thomas, Flemingites (Carruthers) Brack-Hanes \& Thomas and Sigillariostrobus Schimper. Lepidostrobus cones are represented by four species/specimens that can be subdivided into two groups based on their in situ spores. L. boltonensis n. sp., L. huttonii n. sp. and L. spinosus Kidston contain cingulizonate lycospores with relatively narrow cingulum and narrow zona which are comparable with the dispersed species Lycospora subjuga Bharadwaj, L. brevijuga Kosanke, L. triangulata Bharadwaj, L. microgranulata Bharadwaj or L. contacta Habib. The cone L. cf. obovatus yielded in situ lycospores with narrow cingulum and wide zona similar to those of the dispersed species Lycospora loganii (Wilson) Potonié \& Kremp, $L$. pellucida (Wicher) Schopf, Wilson \& Bentall, L. micropapillata (Wilson \& Coe) Schopf, Wilson \& Bentall, L. micrograna Hacquebard \& Barss, L. intermedia (Wilson \& Hoffmeister) Wilson \& Hoffmeister, L. pseudoannulata Kosanke and L. perforata Bharadwaj \& Venkatachala. The genus Flemingites is represented by F. cf. russelianus Binney. The Flemingites cone yields in situ microspores identified as the Lycospora orbicula-type. Sigillarian cones are rare and were represented by a single specimen of Sigillariostrobus acicularis n. sp. which contained Crassispora kosankei-type microspores. Only one of these British species (Lepidodendron cf. obovatus) is unequivocally present in the coalfields of central and western Bohemia. It is probable that Flemingites cf. russelianus also occurs in both areas. Key words: Lepidostrobus, Flemingites, Sigillariostrobus, in situ spores, Lycospora, Crassispora.
\end{abstract}

OPLUŠTIL, S. \& BEK, J. 2009. Some Pennsylvanian arborescent lycopsid cones and their microspores from the British coalfields. Bulletin of Geosciences 84(2), 203-226 (7 figures, 5 tables). Czech Geological Survey, Prague. ISSN 1214-1119. Manuscript received June 3, 2008; accepted in revised form January 26, 2009; published online March 27, 2009; issued June 30, 2009.

Stanislav Opluštil, Department of Geology and Palaeontology, Charles University in Prague, Faculty of Sciences, Albertov 6, 12843 Praha 2, Czech Republic; oplustil@natur.cuni.cz・Jiři Bek, Department of Palaeobiology and Palaeoecology, Institute of Geology v.v.i., Academy of Sciences, Rozvojová 269, 16500 Praha 6, Czech Republic; bek@gli.cas.cz.

Remains of arborescent lycopsids are among the most common fossils in the Late Palaeozoic coal deposits of the equatorial Amerosinian floral province (Opluštil \& Cleal 2007; Thomas 1978, 2007). Because of their spectacular tree habit whole plants are rarely preserved. Typically, isolated organs or other fragments are found in the fossil record. Specimens showing the connection of particular organs and/or aspects of whole plant architecture are much less common. This is the main reason that our knowledge of the correlation of isolated organs to parent plants and the whole plant reconstruction of particular species remain quite incomplete, despite nearly two centuries of palaeobotanical research (Philips \& DiMichele 1992, Bateman 1994). Individual organs found in isolation are given their own taxonomic names (Chaloner 1986, 1999; Meyen 1987; Forey et al. 2004; McNeill et al. 2006). Also, there is a range of morphological variablility among organ systems and preservation states that leads to further taxonomic complexity (Chaloner 1986). For example, several tens of species of the Pennsylvanian lycopsid genus Sigillaria Brongniart have been described based on bark impressions, but only a handful of cone species are known. Lepidodendrid cones illustrate an additional problem where the species often display gradations in their morphology and size. This variation results in very slight differences among species, frequent misinterpretations and a rich synonymy (Chaloner 1986). Progress in understanding the affinities of arborescent lycopsid fructifications requires careful examination of additional characteristics. The attachment of parts, such as the combination of the cone and the leafy stem on which it was borne, is especially important, but information of this sort 


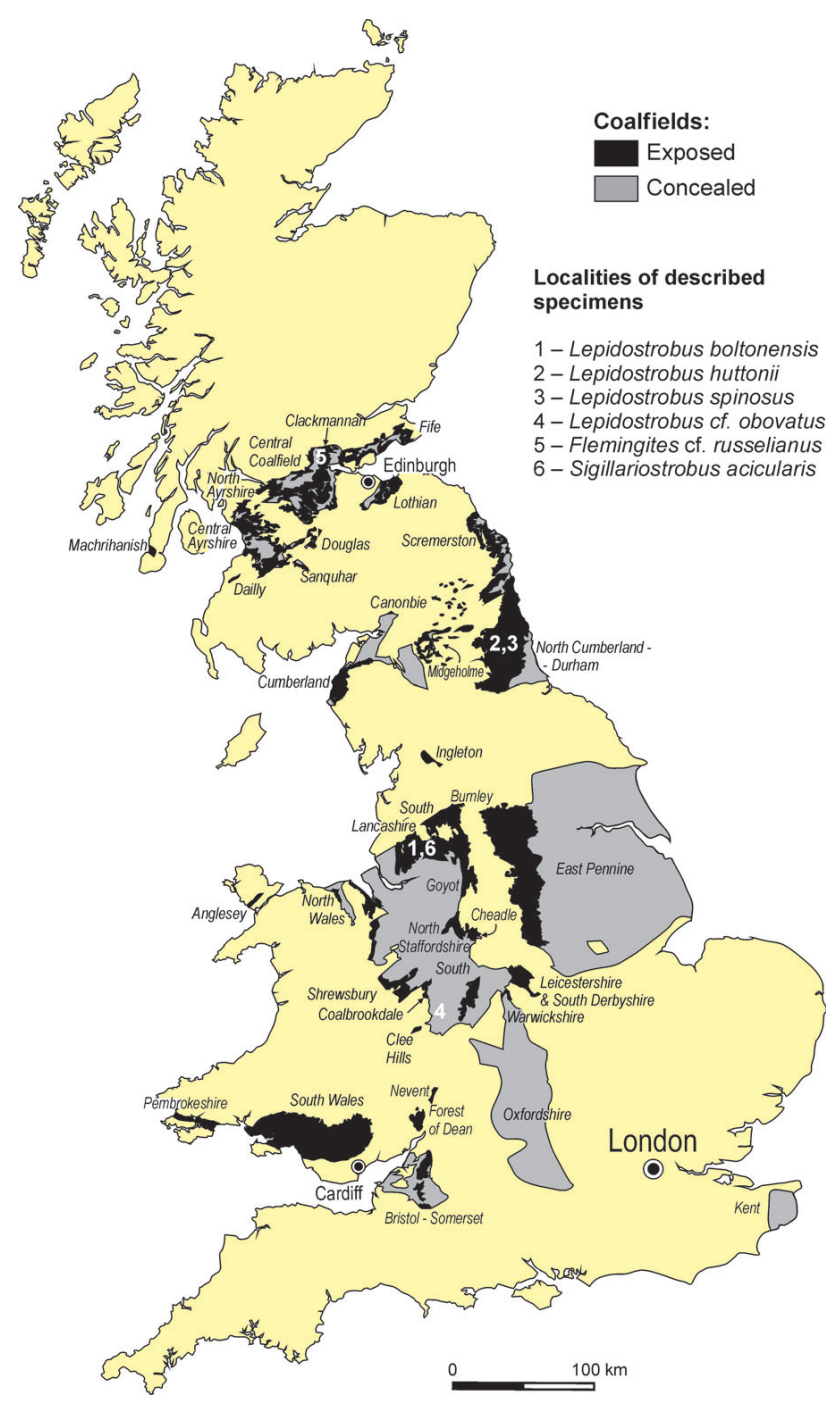

Figure 1. Carboniferous coalfields of Great Britain with location of specimens described herein. According to Chapman (1999).

is only rarely found. Another key source of additional information is the use of in situ spores released through the maceration of cones (Chaloner 1953a, 1953b, 1967; Thomas 1965, 1970, 1987; Thomas \& Dytko 1980; Brack-Hanes \& Thomas 1983; Thomas \& Brack-Hanes 1991). This provides an important additional source of new taxonomic information from the cones themselves. Our primary aim here is to document the palynomorph content of selected well-preserved lycopsid cones from the British coalfields. We also review the evidence of cone morphology and, where known, the nature of the leafy foliage on which the cones were borne. This combination of morphological characteristics significantly improves our knowledge of particular species, facilitating comparisons with material elsewhere. We compare the British species with similar forms from the Czech coalfields to clarify their stratigraphic and geographic distribution.
This study establishes the utility of this general approach. The large numbers of such cone specimens in museum collections around the world provides an invaluable source of materials for refining the taxonomic framework of tree lycopods and for developing a better understanding of their stratigraphic and geographic ranges.

\section{Overview of the study of the Pennsylvanian arborescent lycopsids of Great Britain}

Palaeobotanical research in the Late Carboniferous has a very long tradition in the British Isles that dates back to the beginning of the $19^{\text {th }}$ century, when the mining of coal served as a base for rapid industrial development. The purpose of this overview is not to provide a complete list of all the researchers, but to point out those who significantly contributed to our present-day knowledge of the Carboniferous lycopsids of Britain. In 1804, Parkinson figured as a "strobilus" a lepidodendrid cone from the Middle Coal Measures strata (Duckmantian) of Derbyshire, East Pennines, UK. This specimen, which is now stored in the collection of the Natural History Museum in London (No. V 16440), was later assigned by Brongniart (1828) to his Lepidostrobus ornatus Brongniart, representing the first described taxonomic fructification of Carboniferous arborescent lycopsids. Later, Lindley \& Hutton (1831-1837) described several other species which they included in the genus Lepidostrobus and isolated sporophylls in Lepidophyllum Brongniart (now Lepidostrobophyllum Hirmer). In the second half of the $19^{\text {th }}$ century, Binney (1870-1875) published several species from the British Coal Measures. Around the turn of the $19^{\text {th }}$ and $20^{\text {th }}$ centuries, Kidston (e.g., 1889, 1891, 1893), one of the most famous British palaeobotanists, described several new species and revised some existing taxa. Just a few years later, Arber (1922-1924) revised British lepidostrobuses and distinguished fourteen species, which he further subdivided into three subgenera; Eulepidostrobus Arber, Ortholepidostrobus Arber and Sublepidostrobus Arber, based on the size of distal laminae compared to that of the pedicel. Arber (1922-1924) also took into account whether the cones were homosporous or heterosporous, however, he used this character only at the specific level. He also realised the importance of parent plants, but he correlated some cone species to more than one parent plant, thus clearly illustrating the artificial character of this cone classification. Strobili borne on several different parent plant species can be grouped as a single cone species because of their similar morphology (Němejc 1954). A new approach in the study of the Carboniferous lycopsid fructifications was introduced by Chaloner (e.g., 1953a, 1953b, 1967), who combined cone morphology with in situ spores. At the same time, Crookall (1964, 1966), in 
Stanislav Opluštil \& Jiří Bek • Some Pennsylvanian arborescent lycopsid cones and their microspores from the British coalfields

Table 1. The diameter (d), cingulum (c) and zona widths (z), sculptures of proximal and distal surfaces of British in situ lycospores and their parent cones

\begin{tabular}{lccccc}
\hline \multirow{2}{*}{ cones } & \multicolumn{4}{c}{ in situ lycospores } \\
\cline { 2 - 6 } & $\mathrm{d}(\mu \mathrm{m})$ & $\mathrm{c}(\mu \mathrm{m})$ & $\mathrm{z}(\mu \mathrm{m})$ & sculpture of proximal surface & sculpture of distal surface \\
\hline Lepidostrobus boltonensis & $29(31.5) 35$ & $2.6(3.3) 4.2$ & $1.2(2.2) 2.5$ & laevigate, finely scabrate & microgranulate \\
Lepidostrobus spinosus & $29(33.8) 35$ & $2.0(2.7) 3.9$ & $1.3(2.2) 3.3$ & laevigate, finely scabrate & densely microgranulate \\
Lepidostrobus huttonii & $28(32.3) 35$ & $2.5(3.1) 3.8$ & $1.2(1.5) 2.1$ & finely microgranulate & densely microgranulate, granulate \\
Lepidostrobus cf. obovatus & $38(41.2) 43$ & $1.6(1.8) 2.0$ & $3.0(4.2) 5.6$ & finely microgranulate & densely microgranulate, granulate \\
Flemingites cf. russelianus & $26(32.6) 37$ & $0.8(1.3) 2.0$ & - & laevigate, finely scabrate & densely microspinate \\
\hline
\end{tabular}

his monograph, provided a thorough revision of Carboniferous lycopsids of the British Coal Measures. In the Pennine Basin he distinguished seventeen species of lepidodendrid fructifications and the same number of parent plants. He did not, however, study their in situ spores, and the species described are distinguished mostly on the basis of cone morphology, with the exception of a few species previously described by Chaloner (1953a, 1953b, 1967). The importance of in situ spores as a part of lycopsid cone diagnoses was than stressed by Thomas (1965, 1970, 1987), Thomas \& Dytko (1980), Brack-Hanes \& Thomas (1983) and Thomas \& Brack-Hanes (1991) who studied cones and their spores from the British coalfields. The works of these authors as well as those of Chaloner can be considered as the basis for modern study of this complex plant group.

\section{Generic concepts of the Carboniferous arborescent lycopsid fructifications}

Since Brongniart (1828) established Lepidostrobus as the first Carboniferous arborescent lycopsid cone genus, many other genera, as well as opinions on their concepts, have appeared in the literature. These are discussed in detail by Brack-Hanes \& Thomas (1983), Thomas \& Brack-Hanes (1991), and Bek \& Opluštil (2004, 2006). Current concepts of lycopsid cone genera are based not only on cone morphology, but also on whether they are seed-like or free sporing, monosporangiate or bisporangiate, and the types of spores they produced. Another important feature is the mode of preservation (i.e. adpression, permineralization), as independent generic names are usually used for each type of preservation (McNeill et al. 2006). Thus, the genus Lepidostrobus was restricted by Brack-Hanes \& Thomas (1983) exclusively to monosporangiate, Lycospora-producing cones (excluded Lycospora orbicula-type), whereas bisporangiate lepidodendrid cones belong to the genus Flemingites. Anatomically preserved permineralized seed-like fructifications containing one megaspore tetrad with three abortive and one functional megaspore are classified as Lepidocarpon Scott if the megaspores are integumented or Achlamydocarpon (Schumacker-Lambry,
1966) if they are non-integumented. Compressed specimens are typically assigned to Lepidocarpon, whereas Lepidocarpopsis Abbott, introduced by Abbott (1963), could possibly be an equivalent to the petrified genus Achlamydocarpon. The classification of sigillarian cones is relatively straightforward. It was believed that these plants bore only monosporangiate cones producing either Crassispora (Bharadwaj) Sullivan microspores or Laevigatisporites Ibrahim or Tuberculatisporites Ibrahim megaspores. Both are classified as Sigillariostrobus if preserved flattened or Mazocarpon Benson if petrified. However, the recent discovery of new sigillarian cone Nudasporestrobus Feng et al. (Feng et al. 2008) from the Chinese Late Carboniferous which bears Sublagenicula-type megaspores reveals that even Sigillaria is an artificial taxon rather than monophylletic genus. Cones documented here belong to the genera Lepidostrobus, Flemingites and Sigillariostrobus.

\section{Material and methods}

All of the specimens described in this study are housed in the collection of the Natural History Museum in London, UK. The materials were examined by the authors during a research visit funded by the SYNTHESYS Programme in 2006. From more than 200 cones stored in this collection, sampling for palynomorphs was allowed on only fifteen examples. A small amount of coaly matter, representing very small fragments of sporangia, was removed from 15 specimens. Of these, only six yielded in situ spores after maceration. These are specimen numbers BMNH V.5888, BMNH V.12045A, BMNH 36465, BMNH 40587, BMNH V.65201b and BMNH V.65200.

Spores were recovered by dissolving small portions of the cones (separated from the cone species with a mounted needle) in nitric acid for 24-48 hours and $\mathrm{KOH}$ for 1-2 hours. Most of the released spores were then mounted in glycerine jelly for direct microscopic examination.

Microspores obtained from the studied cones were classified according to the system of dispersed spores suggested by Potonié \& Kremp (1954, 1955), Dettmann (1963) and Smith \& Butterworth (1967). In situ spores 
Table 2. The diameter (d), cingulum (c) and zona (z) widths and sculptures of proximal and distal surfaces of selected Carboniferous adpressed in situ lycospores and their parent cones. View of selected Flemingites cones and their in situ micro- and megaspores

\begin{tabular}{|c|c|c|c|c|c|c|}
\hline lycospore /parent cone & $\mathrm{d}(\mu \mathrm{m})$ & $\mathrm{c}(\mu \mathrm{m})$ & $\mathrm{z}(\mu \mathrm{m})$ & $\begin{array}{l}\text { sculpture of } \\
\text { proximal surface }\end{array}$ & sculpture of distal surface & reference \\
\hline $\begin{array}{l}\text { Lycospora perforata /Lepidostrobus } \\
\text { barnsleyensis }\end{array}$ & 14 & 2.5 & 3 & microgranulate & laevigate & Thomas 1965 \\
\hline Lycospora sp./ Lepidostrobus comosus & 17 & 5 & 2 & microgranulate & microgranulate & Thomas 1965 \\
\hline Lycospora sp./Lepidostrobus sp. C & 16 & 2 & 2 & microgranulate & microgranulate & Hagemann 1966 \\
\hline Lycospora sp./ Lepidostrobus jacksonii & 18 & 2.5 & 2.5 & microganulate & microgranulate, granulate & Thomas 1965 \\
\hline Lycosporal Lepidostrobus sp. D & 17 & 2 & 1.5 & microgranulate & densely microgranulate & Hagemann 1966 \\
\hline Lycospora cf. uber/Lepidostrobus dawsonii & 20.5 & 4.5 & 4 & laevigate & $\begin{array}{l}\text { microgranulate, } \\
\text { microverrucate }\end{array}$ & $\begin{array}{l}\text { Thomas et al. } \\
\text { unpublished }\end{array}$ \\
\hline $\begin{array}{l}\text { Lycospora noctuina/ Lepidostrobus } \\
\text { haslingdenensis }\end{array}$ & 16.45 & 2.25 & 2.9 & $\begin{array}{l}\text { granulate, } \\
\text { microgranulate }\end{array}$ & verrucate, rugulate & Willard 1989b \\
\hline $\begin{array}{l}\text { Lycospora punctata/ Lepidostrobus cf. } \\
\text { squarrosus }\end{array}$ & $15 \cdot 45$ & 3.4 & 3.4 & microgranulate & densely microgranulate & Willard 1989b \\
\hline Lycospora rotunda/ Lepidostrobus sp. A & 15.15 & 5.6 & 2.4 & finely granulate & granulate, rugulate & Willard 1989b \\
\hline $\begin{array}{l}\text { Lycospora torquifer/ Lepidostrobus praelongus, } \\
\text { L. variabilis }\end{array}$ & 15.7 & 3.8 & 3.7 & $\begin{array}{l}\text { verrucate, rugulate, } \\
\text { baculate }\end{array}$ & $\begin{array}{l}\text { densely rugulate, } \\
\text { baculate, verrucate }\end{array}$ & Willard 1989b \\
\hline $\begin{array}{l}\text { Lycospora noctuina/ Lepidostrobus } \\
\text { haslingdenensis }\end{array}$ & 17.13 & 2.7 & 3 & scabrate, laevigate & microspinate & Thomas \& Dytko 1980 \\
\hline Lycospora perforata/ Lepidostrobus binneyanus & 13.5 & 2 & 4 & microgranulate & laevigate & Thomas 1988 \\
\hline Lycospora granulatal Lepidostrobus ornatus & 14 & 2.5 & 3 & $\begin{array}{l}\text { granulate, } \\
\text { microgranulate }\end{array}$ & $\begin{array}{l}\text { densely granulate, } \\
\text { microgranulate }\end{array}$ & $\begin{array}{l}\text { Brack-Hanes \& } \\
\text { Thomas } 1983\end{array}$ \\
\hline Lycospora punctata/ Lepidostrobus stephanicus & 18 & 2.6 & 2.1 & $\begin{array}{l}\text { microspinate, } \\
\text { microgranulate }\end{array}$ & $\begin{array}{l}\text { densely microspinate, } \\
\text { microgranulate }\end{array}$ & Bek \& Opluštil 2004 \\
\hline Lycospora triangulata/ Lepidostrobus nemejcii & 18 & 2.5 & 1.9 & $\begin{array}{l}\text { microverrucate, } \\
\text { microgranulate }\end{array}$ & $\begin{array}{l}\text { densely microverrucate, } \\
\text { microgranulate }\end{array}$ & Bek \& Opluštil 2004 \\
\hline $\begin{array}{l}\text { Lycospora cf. uzunmehmedii/ Lepidostrobus } \\
\text { thomasii }\end{array}$ & 18 & 2.9 & 3.9 & $\begin{array}{l}\text { laevigate, finely } \\
\text { scabrate }\end{array}$ & microgranulate & Bek \& Opluštil 2004 \\
\hline Lycospora rotunda/ Lepidostrobus ronnaensis & 19 & 3.9 & 3.8 & $\begin{array}{l}\text { laevigate, finely } \\
\text { scabrate }\end{array}$ & Microverrucate, verrucate & Bek \& Opluštil 2004 \\
\hline Lycospora loganii/Lepidostrobus obovatus & 18 & 2.7 & 2 & $\begin{array}{l}\text { microverrucate, } \\
\text { verrucate }\end{array}$ & microverrucate & Bek \& Opluštil 2004 \\
\hline Lepidostrobus kohoutii & 18.1 & 3.3 & 4.5 & $\begin{array}{l}\text { laevigate, finely } \\
\text { scabrate }\end{array}$ & $\begin{array}{l}\text { microspinate, } \\
\text { microgranulate }\end{array}$ & Bek \& Opluštil 2006 \\
\hline Lepidostrobus cf. haslingdenensis & 19.6 & 2.6 & 4.4 & $\begin{array}{l}\text { laevigate, finely } \\
\text { scabrate }\end{array}$ & densely microspinate & Bek \& Opluštil 2006 \\
\hline Lepidostrobus sp.A & $22 \cdot 3$ & 2.2 & 2.6 & $\begin{array}{l}\text { microgranulate, } \\
\text { granulate }\end{array}$ & $\begin{array}{l}\text { densely microgranulate, } \\
\text { granulate }\end{array}$ & Bek \& Opluštil 2006 \\
\hline Lepidostrobus sp. B & 22.5 & 2.6 & 2.7 & $\begin{array}{l}\text { microgranulate, } \\
\text { granulate }\end{array}$ & $\begin{array}{l}\text { densely microgranulate, } \\
\text { granulate }\end{array}$ & Bek \& Opluštil 2006 \\
\hline Lepidostrobus sp. C & 16.3 & 2.7 & 2 & $\begin{array}{l}\text { microgranulate, } \\
\text { granulate }\end{array}$ & microgranulate, granulate & Bek \& Opluštil 2006 \\
\hline Lepidostrobus sp. D & 18.5 & 2.6 & 2 & microgranulate & densely microgranulate & Bek \& Opluštil 2006 \\
\hline
\end{tabular}

were compared directly with the original diagnoses (holotypes), descriptions and illustrations of dispersed species. Species determinations were based only on these original diagnoses, and not on the interpretations of subsequent authors. Comparisons were made with other lycospores isolated from various Lepidostrobus cones preserved as adpressions and petrifactions, whereas cones were compared only with adpression species.
Described cone specimens and palynological slides are housed in the Natural History Museum, London, UK. Digital photomicrographs of in situ spores are stored in the Institute of Geology v.v.i., Academy of Sciences of the Czech Republic, Prague and the Natural History Museum, London, UK. Digital photographs of cones are in the Faculty of Sciences, Charles University, Prague and Natural History Museum, London, UK. 
Table 3. The diameter (d), cingulum (c) and zona (z) widths and sculptures of proximal and distal surfaces of selected permineralized (coal-balls) in situ lycospores and their parent cones

\begin{tabular}{|c|c|c|c|c|c|c|}
\hline lycospore /parent cone & $\mathrm{d}(\mu \mathrm{m})$ & $\mathrm{c}(\mu \mathrm{m})$ & $\mathrm{z}(\mu \mathrm{m})$ & $\begin{array}{l}\text { sculpture of } \\
\text { proximal surface }\end{array}$ & $\begin{array}{l}\text { sculpture of distal } \\
\text { surface }\end{array}$ & reference \\
\hline $\begin{array}{l}\text { Lycospora sp./Lepidostrobus oldhamius } \\
\text { (associated with Lepidophloios harcourtii) }\end{array}$ & 17 & 4 & 6 & laevigate & $\begin{array}{l}\text { microspinate, } \\
\text { microgranulate }\end{array}$ & Willard 1989a \\
\hline $\begin{array}{l}\text { Lycospora cf. perforata/ Lepidostrobus } \\
\text { fayettevillense }\end{array}$ & 23 & 3 & 4 & $\begin{array}{l}\text { laevigate, finely } \\
\text { microgranulate }\end{array}$ & $\begin{array}{l}\text { densely } \\
\text { microgranulate }\end{array}$ & Taylor \& Eggert 1968 \\
\hline Lycospora sp./Lepidostrobus coulterii & 13 & 1.5 & 2.5 & microgranulate & $\begin{array}{l}\text { densely } \\
\text { microgranulate }\end{array}$ & Balbach 1966 \\
\hline Lycospora sp./ Lepidostrobus minor & 13 & 2 & 3 & microgranulate & microgranulate & Leisman \& Rivers 1974 \\
\hline
\end{tabular}

Measurements and the type of sculptures of proximal and distal surfaces of Bohemian in situ lycospores are given in Table 1. It was possible to compare our results only with papers where a good description or precise measurements of in situ spores have been made. Therefore, we used only data reported by the following authors for comparisons: Thomas (1965, 1970, 1987, 1988), Willard (1989b), Thomas \& Dytko (1980), Brack-Hanes \& Thomas (1983), Hagemann (1966) and Bek \& Opluštil (1998, 2004, 2006) from adpressed specimens and from permineralized specimens (coal-balls) published by Felix (1954), Balbach (1966), Taylor \& Eggert (1968), Leisman \& Rivers (1974) and Willard (1989a). Data from these in situ lycospores are given in Table 2 (adpressed specimens) and Table 3 (permineralized specimens). A review of sigillarian in situ micro- and megaspores is on Table 4.

\section{Systematic palaeontology}

The cones that provided spores can be subdivided into genera Lepidostrobus, Flemingites and Sigillariostrobus. The genus Lepidostrobus is represented by specimens Nos BMNH V.12045A, BMNH 36465, BMNH 40587 and BMNH V.65201b. Specimen BMNH V.5888 belongs to the genus Flemingites, and specimen No. BMNH V.65200 is a representative of the genus Sigillariostrobus. Specimens classified as Lepidostrobus can be subdivided into two groups based on their in situ spores and their cone morphology. The first group represents rather small cylindrical to oval cones (Nos BMNH V.12045A, BMNH 36465 and BMNH 40587), the in situ spores of which can be compared with dispersed species Lycospora subjuga, L. brevijuga, L. triangulata, L. microgranulata and L. contacta. These spores are characterised by relatively narrow cingulum and narrow zona. The second group is represented only by specimen No. BMNH V.65201b which provided lycospores with narrow cingulum and wide zona compared with the dispersed species Lycospora loganii, L. pellucida, L. micropapillata, L. microgranna, L. intermedia, L. pseudoanullata and L. perforata. Morphology of this cone differs from those of the first group.
Class Lycopsida Scott, 1909

Order Lepidocarpales Thomas \& Brack-Hanes, 1984

Genus Lepidostrobus (Brongniart) Brack-Hanes \& Thomas, 1983

Type species. - Lepidostrobus ornatus Brongniart, 1828.

Lepidostrobus boltonensis sp. nov.

Figure 2

Material. - Specimen BMNH V.12045A.

Locality. - Chequerbent Pit, Bolton, South Lancashire Coalfield.

Stratigraphy. - Lower Coal Measures (Langsettian), Roof of the Royal Arley Coal.

Etymology. - According to Bolton, the type locality in South Lancashire.

Diagnosis. - Cone cylindrical or only very slightly tapering with blunt apex and base, more than $72 \mathrm{~mm}$ long and 21-22 $\mathrm{mm}$ wide including distal laminae. Cone axis 2 to $2.2 \mathrm{~mm}$ in diameter, with sporophylls attached in helix of about $30^{\circ}$ and at an angle between $70^{\circ}$ near the apex and $90^{\circ}$ at and near the base. Pedicels between 4 and $9 \mathrm{~mm}$ long, laminae triangular, with entire margins slightly concave, about 5 to $6 \mathrm{~mm}$ long and slightly bent to the cone apex, adpressed to the cone. Sporangia oval, 4-9 mm long and about 1.5 to $2 \mathrm{~mm}$ high, microsporangiate. Microspores subtriangular to subcircular trilete with narrow cingulum and zona. Proximal and distal surfaces irregularly scabrate, finely or densely microgranulate, microverrucate or microspinate.

Description. - Cone: This specimen consists of a mudstone slab containing remains of three isolated cones, which are all of the same size and morphology and apparently belong to the same species (Fig. 2A). They are preserved as adpressions split mostly along the cone surface but locally also 
along the cone axis. Arrangement of pedicels and axis width are overprinted and can be partly observed.

The most complete specimen is a $72 \mathrm{~mm}$ long cone that lacks a base (Fig. 2A, D). The other specimens comprise a $66 \mathrm{~mm}$ long cone fragment with detached apex and a $40 \mathrm{~mm}$ long fragment of the middle part of a cone without apex and base. All of the specimens represent cylindrical cones of the same width, which vary only a little between 21 and $22 \mathrm{~mm}$ due to distal laminae spreading. Cones start to taper about $12 \mathrm{~mm}$ in front of the apiculate apex (Fig. 2D). Similarly, the cones taper to a truncate or slightly cordate base. The length of the complete cone is estimated to be about $90 \mathrm{~mm}$, with an estimated length/width ratio of 4.5. The axis is 2 to $2.2 \mathrm{~mm}$ wide throughout its whole length (Fig. 2A-D). The pedicels are attached to the cone axes at an angle that varies from perpendicular insertion at and near the base to $70^{\circ}-80^{\circ}$ near the middle part of the cone length. This angle further decreases to about $65^{\circ}$ near the apex where the cone starts to taper. Pedicels are 8-9 mm long, but in the apical and basal parts decrease to as little as $4-5 \mathrm{~mm}$. Their morphology is not clearly seen because they are covered by imbricated laminae and only the outline is overprinted on the cone surface. The outline indicates that they are slightly triangular in lateral view (Fig. 2E). The pedicels appear to be densely spaced; however, it is not possible to directly measure the distance due to preservation. Sporangia are oval and have the same length as pedicels, between 1.5 and $2 \mathrm{~mm}$ high. The laminae are short, triangular, 5-6 mm long, gently bent upward and adpressed to the cone body.

Spores: Subtriangular to subcircular trilete microspores 29 (31.5) $35 \mu \mathrm{m}$ in diameter. The laesurae is simple, extending to the outer margin of the central body. Cingulum 2.6 (3.3) $4.2 \mu \mathrm{m}$ wide developed as a dark thickened ring on the outer margin of the central body. Zona may be sometimes perforated and usually is laevigate to finely scabrate, 1.2 (2.2) $2.5 \mu \mathrm{m}$ wide. Proximal and distal surfaces are irregularly scabrate, finely or densely microgranulate, microverrucate or microspinate (Fig. 2F, G). The number of sculpture elements is higher on the distal than on the proximal surface.

Parent plant: The specimen described here contains only isolated cones that do not provide any information about the parent plant. There is no other similar cone in the collection of the Natural History Museum in London that could be assigned to this species or could have provided any information on the parent plant.

Comparisons and discussion. - In situ spores isolated from the largest cone fragment belong to the subgroup of cingulizonate lycospores with relatively narrow cingulum and narrow zona (Bek \& Opluštil 2006) and can be correlated to the dispersed miospore species Lycospora subjuga, L. brevijuga, L. triangulata, L. microgranulata or L. contacta.
Similar spores were isolated by Bek \& Opluštil (2004, 2006) also from Lepidostrobus nemejcii Bek \& Opluštil, L. sp. C and $L$. sp. D from the Late Palaeozoic continental basins of the Czech Republic. However, all of these species differ in cone morphology and cone size. L. nemejcii is a large cylindrical cone, several tens of centimetres long and $90 \mathrm{~mm}$ wide. Remaining species are rather poorly known, and would not be reliable for comparison with $L$. boltonensis. However, some morphological features (cone axis, cone width or laminae shape, etc.) indicate that they are rather different species. A similar type of in situ lycospore was described by Hagemann (1966) from the cone adpression of $L$. sp. D from the Westphalian of the Campine Basin, Belgium. This specimen is an $84 \mathrm{~mm}$ long fragment of the middle part of a cylindrical cone that is 20 to $25 \mathrm{~mm}$ wide, depending on whether the laminae are included or not. Laminae are relatively short, lanceolate, and with apparently concave margins on their upper triangular part, and are different from those of L. boltonensis described here. Another difference seems to be the much thicker axis of the Belgian specimen. The ratio between pedicel length and axis width is 3.4 for L. boltonensis but only 0.95 for the Belgian cone, which, again, indicates that these cones belong to different species. In situ lycospores isolated from permineralized (coal-balls) specimens of L. coulterii Felix by Balbach (1966) and L. minor Leisman \& Rivers by Leisman \& Rivers (1974) are also of similar morphology, however, the cones themselves are difficult to compare because of different modes of preservation.

Based on cone morphology, the specimens described here have the greatest similarity to Lepidostrobus spinosus Kidston, L. jacksoni Arber, L. obovatus (Rénier) Bek \& Opluštil, L. haslingdenensis Thomas \& Dytko and L. sp. D Bek \& Opluštil. Kidston's specimens of Lepidostrobus spinosus comprise small, nearly cylindrical cones from the Somerset (Asturian) and Ayrshire (Duckmantian) coalfields. The morphology of Kidston's syntypes (Kidston's collection Nos 712,1548 ) is very similar to that of the specimens described here, with the exception that the axis is about twice as wide in the Kidston specimens. In situ microspores of the Kidston syntypes are known only from specimen No. 1548, which provided a morphologically similar type of in situ lycospore (i.e. with relatively narrow cingulum and narrow zona (Fig. 2F, G). Nevertheless, differences in axis width point to the conclusion that the specimen described here and Lepidostrobus spinosus are different species.

Another morphologically similar form is L. jacksonii, which has a closer resemblance to L. boltonensis than the previous species. It is a small cylindrical cone of the same size as L. boltonensis. It can be clearly distinguished by its 6-7 mm thick wide stalk, which is a common feature of all known specimens. Spores of permineralized specimen interpreted as L. jacksonii were macerated by Felix (1954) 

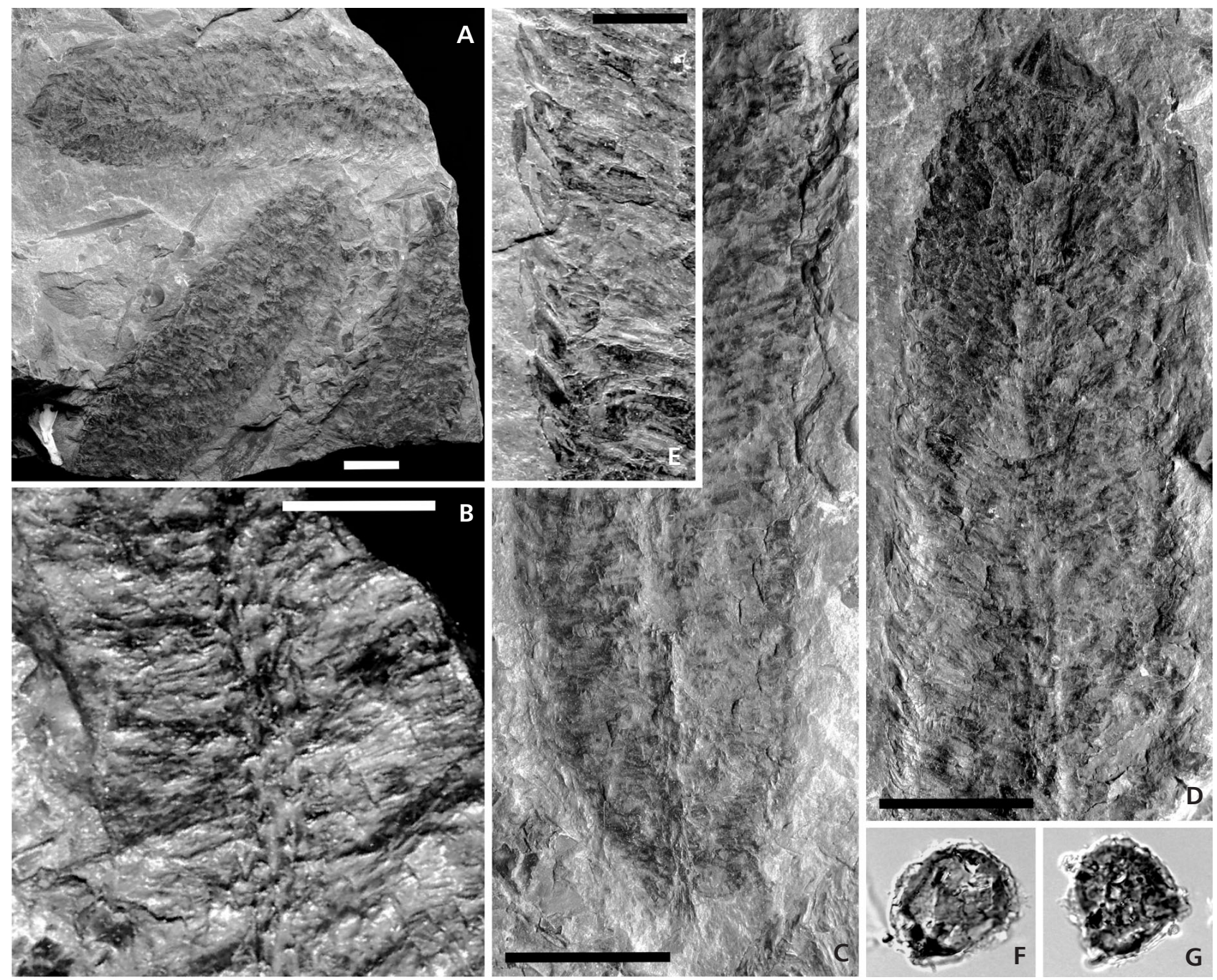

Figure 2. Lepidostrobus boltonensis n. sp. • A - specimen BMNH V.12045A (the holotype), from Chequerbent Pit, Bolton, South Lancashire Coalfield. Lower Coal Measures (Langsettian), Roof of the Royal Arley Coal, scale bar $10 \mathrm{~mm}$. $\bullet$ - detail view of the smallest cone fragment from the same specimen, scale bar $10 \mathrm{~mm}$. $\bullet \mathrm{C}$ - detail of the cone with preserved base, scale bar $10 \mathrm{~mm}$. $\bullet \mathrm{D}$ - cone fragment with preserved apex. This specimen provided spores, scale bar $10 \mathrm{~mm}$. $\bullet \mathrm{E}$ - detail of sporophylls of the specimen that provided spores, scale bar $5 \mathrm{~mm}$. $\bullet \mathrm{F}$, G - in situ trilete cingulizonate lycospores with relatively narrow cingulum and narrow zona, all $\times 500$.

who obtained different types of cingulate and not cingulizonate lycospores similar to those of L. boltonensis. This difference in spore types supports the idea about its questionable classification. On the other hand, Thomas (1965) described cingulizonate lycospores with wide cingulum and wide zona from an adpression specimen also assigned to L. jacksonii. These in situ lycospores described from Lepidostrobus jacksonii by Thomas (1965) are different from those isolated by us from L. boltonensis and from specimen assigned to L. jacksonii by Felix (1954).

L. obovatus is another similar species which comprises cones of comparable size and morphology. They can be distinguished from L. boltonensis by their oval shape, which tapers gently from the mid point of the cone towards both ends. Moreover, L. obovatus is commonly attached to the leafy shoots of Lepidodendron mannabachense Sternberg (=L. obovatum Sternberg), which is not the case for the specimen described here. Lepidostrobus obovatus also differs in having longer laminae. More importantly, the in situ spores of L. obovatus are also different from those of L. boltonensis. Those of the L. obovatus were described by Bek \& Opluštil (2004) and compared with the dispersed species Lycospora loganii, which is characterised by narrow cingulum and wide zona.

L. haslingdenensis described from the Late Namurian of the Lancashire Millstone Grit is similar to L. boltonensis in being a rather small cylindrical cone of the same width. However, it can be distinguished by its wider axis that is about 3-5 $\mathrm{mm}$ thick compared to the $2 \mathrm{~mm}$ thickness of L. boltonensis. Laminae of both species are generally short, 
but those of L. haslingdenensis are even shorter. However, as stated by Thomas \& Dytko (1980), length of laminae can be related to rather poor preservation. In situ lycospores isolated from L. haslingdenensis are of a different type (relatively wide cingulum and wide zona) than those of $L$. boltonensis (relatively narrow cingulum and narrow zona).

Willard (1989b), who obtained spores from 61 lycopsid cones from the North American and British coalfields, described a similar type of cingulizonate lycospores with relatively narrow cingulum and narrow zona from two adpression cone species Lepidostrobus variabilis Lindley \& Hutton (Langsettian-Bolsovian of the Illinois and Appalachian basins) and L. praelongus Lesquereux (Asturian of Pennsylvania). Willard (1989b) compared lycospores isolated from both cone species to the dispersed spore species Lycospora torquifer (Loose) Potonié \& Kremp. Another similar type of in situ lycospore of the Lycospora punctata-type was described by Willard (1989b) from adpression specimens of Lepidostrobus cf. squarrosus from the Asturian or Cantabrian of the Forest of Dean, England. L. variabilis of Willard (1989b) is generally a larger cone which is up to $180 \mathrm{~mm}$ long, $17-31 \mathrm{~mm}$ wide, and with an axis 3-7 mm thick. Cones gradually taper from the middle part to the apex. Only laminas are generally similar in shape. Nevertheless, above mentioned differences clearly indicate that Willard's (1989b) L. variabilis and the specimen described here represent different species. Even more apparent morphological differences exist between $L$. boltonensis and Willard's L. praelongus. The latter is a type of large lycopsid cone which is about $210 \mathrm{~mm}$ long and $40-60 \mathrm{~mm}$ wide. The axis is 8 to $10 \mathrm{~mm}$ thick, and also the laminae are generally larger, up to $20 \mathrm{~mm}$ long. The greatest similarity exists between the specimens described here and Willard's (1989b) L. cf. squarrosus from Forest of dean, U.K. She depicted an oval cone, about $80 \mathrm{~mm}$ long and $18-22 \mathrm{~mm}$ wide, similar in size to L. boltonensis. However, it can be distinguished from L. boltonensis by its oval outline, and most probably represent a different species.

Stratigraphic range and geographic distribution. - This species is known only from the holotype, which comes from the Lower Coal Measures (Langsettian) of the South Lancashire Coalfield.

\section{Lepidostrobus huttonii sp. nov.}

Figure 3

Material. - Specimen BMNH 36465.

Locality. - Jarrow, Durham, North Cumberland-Durham Coalfield.

Stratigraphy. - Coal Measures, Westphalian.
Etymology. - In honour of W. Hutton, an early British palaeobotanist.

Diagnosis. - Cone oval, about $68 \mathrm{~mm}$ long and about $20 \mathrm{~mm}$ wide at its mid point. Length/width ratio 3.4. Cone axis $1.5 \mathrm{~mm}$ wide. Laminae triangular, 8-9 $\mathrm{mm}$ long, with entire margins slightly concave. Cone microsporangiate. Parent plant with rhomboidal to roughly hexagonal, slightly imbricated and keeled leaf cushions, slightly longer than wide or as long as wide, between 2.2 and $3.1 \mathrm{~mm}$ wide and/or long. Lower angle acute, remaining angles rounded. Leaf scar rhomboidal, in upper part of leaf cushion, between 1.8 and $2.1 \mathrm{~mm}$ wide and 1.3 and $1.6 \mathrm{~mm}$ long. Microspores subtriangular to subcircular trilete cingulizonate. Proximal and distal surfaces are irregularly scabrate, finely or densely microgranulate to microspinate.

Description. - Cone and sterile shoot: The specimen represents a complete cone attached to a sterile shoot without leaves and preserved as adpression with remains of coally matter (Fig. 3A, B). The cone is split completely along the surface which precludes direct observation of cone architecture beneath the imbricated laminae.

The cone is small, only $68 \mathrm{~mm}$ long and about $20 \mathrm{~mm}$ wide at its mid point. The length/width ratio is 3.4 . The cone is oval to nearly cylindrical, gently tapering from the middle part downward to an obtuse base and upward to a gently pointed apex (Fig. 3A-C). At the cone base, there is a thin, roughly $1.5 \mathrm{~mm}$ wide and $8 \mathrm{~mm}$ long stalk that connects cone and sterile shoot (Fig. 3A, B). This stalk most probably represents the basal part of the cone axis but may also be a decorticated part of a sterile shoot. Single-veined laminae are 8-9 mm long, of narrow triangular shape with entire and slightly concave margins. They are adpressed to the cone. The shoot to which the cone is attached is $9 \mathrm{~mm}$ wide and lacks leaves (which were evidently absent during fossilisation). Leaf cushions are rhomboidal, a little longer than wide or as long as wide, keeled, and directed upward to the cone (Fig. 3A, D). Their surface is smooth, and they are only slightly imbricated. The exposed part is rhomboidal to roughly hexagonal, between 2.2 and $3.1 \mathrm{~mm}$ wide and/or long. The lower angle is acute, remaining ones more or less rounded. The rhomboidal leaf scar is located in the upper part of the leaf cushion. It is about $1.8-2.1 \mathrm{~mm}$ wide and 1.3-1.6 mm long and covers about one third of the leaf cushion. The leaf scar has acute lateral angles and rather rounded upper and lower angles. It bears three foliar prints; a central (vascular) one and smaller parichnos located laterally.

Spores: These are subtriangular to subcircular trilete microspores 28 (32.3) $35 \mu \mathrm{m}$ in diameter (Fig. 3F-I). The laesurae is simple, extending to the outer margin of central body. Cingulum 2.5 (3.1) $3.8 \mu \mathrm{m}$ wide developed as a dark thickened ring on the outer margin of the central body. Zona may occasionally be perforated and usually is laevigate to 

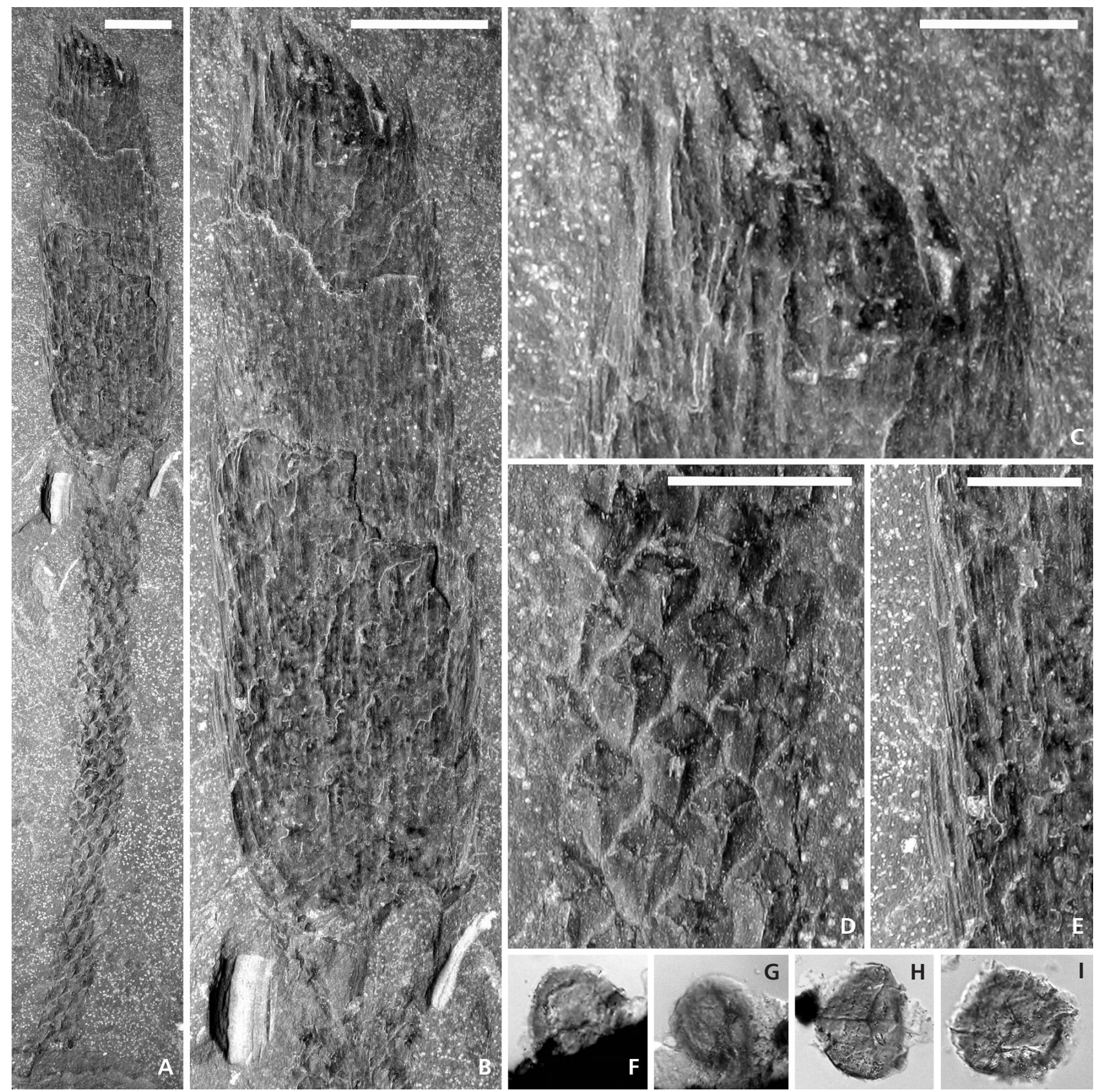

Figure 3. Lepidostrobus huttonii n. sp. • A - cone of Lepidostrobus huttonii n. sp. attached to a leafy shoot of Lepidophloios acerosus Lindley \& Hutton, 1831. Specimen BMNH 36465 (the holotype). Jarrow, Durham, North Cumberland-Durham Coalfield. Coal Measures (Westphalian), scale bar $10 \mathrm{~mm}$. $\cdot \mathrm{B}$ - detail of cone, scale bar $10 \mathrm{~mm}$. $\bullet \mathrm{C}$ - detail of apical part of the cone, scale bar $5 \mathrm{~mm}$. $\bullet \mathrm{D}$ - detail of shoot with leaf cushions, scale bar $5 \mathrm{~mm}$. $\bullet \mathrm{E}-$ detail of sporophylls, scale bar $5 \mathrm{~mm}$; F-I - in situ trilete cingulizonate lycospores with relatively narrow cingulum and narrow zona, all $\times 500$.

finely scabrate and $1.2(1.5) 2.1 \mu \mathrm{m}$ wide. Proximal and distal surfaces are irregularly scabrate, finely or densely microgranulate, microverrucate or microspinate. The number of sculpture elements is higher on the distal than on the proximal surface. Isolated in situ microspores belong to the subgroup of cingulizonate lycospores with relatively narrow cingulum and narrow zona (Bek \& Opluštil 2006) and can be correlated to the dispersed miospore species Lycospora subjuga, $L$. brevijuga, L. triangulata, L. microgranulata or L. contacta.
Parent plant. - The cone is attached to a shoot of Lepidophloios acerosus Lindley \& Hutton. On the specimen label it is identified as Lepidophloios carinatus Weiss, which, as stated by Kidston (1893/4) and Němejc (1947), is a synonym of Lepidophloios acerosus (see also Crookall 1964, p. 315). This species differs from similar Lepidophloios laricinus Sternberg in having apparently keeled leaf cushions that are roughly as wide as long. 
Comparisons and discussion. - If this cone is found isolated without any connection to its parent plant and without any knowledge of its spores, it can easily be mistaken for Lepidostrobus spinosus, L. obovatus or even juvenile stages of $L$. ornatus. The most apparent similarity is to L. spinosus instituted by Kidston (1888) based on a single specimen from Radstock (Asturian/Cantabrian boundary, see Cleal et al. 2003), Somerset Coalfield as nomen nudum. Later, in 1893, he provided full description of the species based on additional material from the Duckmantian (specimens Nos 712 and 1548) of the Kilmarnock Coalfield. These specimens contain several cones of the same size and shape as L. huttonii. L. spinosus cones of specimen No. 712 are widest about a quarter of the way up from the base, compared to L. huttonii where maximum width is achieved at approximately the mid point. The cone of Lepidostrobus huttonii is also more cylindrical compared with that of L. spinosus (No. 1548). However, this is not the case for the remaining Kidston specimen (No 371) from Radstock, which apparears to be a different species (see below), most probably L. obovatus. Spores of $L$. spinosus were obtained only from the Kidston specimen (No. 1548), and probably belong to the same group of cingulizonate lycospores with relatively narrow cingulum and narrow zona (Fig. 3F-I).

Another similar cone species, Lepidostrobus obovatus represents oval to nearly cylindrical cones of comparable size, 65-100 mm long and 18-28 mm wide (Bek \& Opluštil 2004). Some specimens of L. obovatus are indistinguishable from $L$. huttonii when the parent plants and in situ spores are not preserved. Spores of L. obovatus (Lycospora loganii-type) possess a narrow cingulum and wide zona, whereas spores of $L$. huttonii possess a narrow cingulum and narrow zona. The parent plant of L. obovatus is Lepidodendron mannabachense $(=$ L. obovatum), whereas the parent plant of L. huttonii is Lepidophloios acerosus. In addition, most specimens of L. obovatus are oval in shape compared to the nearly cylindrical form of $L$. huttonii.

Comparison of L. huttonii to L. ornatus is complicated because a number of authors have described various cones (species?) from different coalfields as L. ornatus (e.g., Brongniart 1828; Lindley \& Hutton 1831, 1835; Geinitz 1855; Němejc 1954; see also the synonymy in Crookall (1966). Therefore our comparisons are restricted to the holotype, which is a 3-dimensionally preserved specimen in an ironstone nodule lacking distal laminae. It is a $140 \mathrm{~mm}$ long fragment of a nearly cylindrical cone without base or apex, which are broken off. The cone is therefore twice as long as L. huttonii. Spores of the holotype belong to the lycospores with narrow cingulum and wide zona (Brack-Hanes \& Thomas 1983) and thus, they are not of the same type as those of $L$. huttonii.

Lycospores morphologically similar to L. huttonii were isolated from Czech adpression cone species Lepidostrobus sp. C and L. sp. D (Bek \& Opluštil, 2006) and
L. nemejcii by Bek \& Opluštil (2004). All of these Czech specimens, however, differ in their cone morphology and cannot be assigned to any of the British species examined. Hagemann's (1966) specimen of $L$. sp. D from the Campine Basin, Belgium, also provided comparable in situ spores. However, this cone is larger and the sporophylls shorter compared to those of $L$. huttonii, and therefore most probably represent a different species.

Willard (1989b) described a roughly comparable type of in situ lycospores with relatively narrow cingulum and narrow zona from two adpression specimens of Lepidostrobus variabilis (Langsettian-Bolsovian of the Illinois and Appalachian basins) and L. praelongus (Asturian of Pennsylvania). Willard (1989b) compared in situ microspores from both cone species to the dispersed spore species Lycospora torquifer. Willard (1989b) mentioned another similar type of in situ lycospore, the Lycospora punctata-type, isolated from adpression specimens of Lepidostrobus cf. squarrosus from the Asturian of Forest of Dean, England. Of the above mentioned cone species, only $L$. cf. squarrosus is morphologically comparable to L. huttonii. Remaining species represent evidently much larger cones, which cannot be compared with the specimen of L. huttonii described here. L. cf. squarrosus is similar in size and shape to the cones described here, but unfortunately, only a very brief description was provided. Thus, a precise comparison between L. huttonii and L. squarrosus is not possible (Willard 1989b).

\section{Lepidostrobus spinosus Kidston, 1888} Figure 4

Material. - Specimen BMNH 40587.

Locality. - Sunderland, Durham, North Cumberland-Durham Coalfield.

Stratigraphy. - Coal Measures, late Langsettian-early Duckmantian, Westphalian.

Description. - Cone: The specimen is preserved in a grey mudstone slab and represents one complete cone split along the surface showing only limited details of inner morphology overprinted on the cone surface. The cone is oval, 78 $\mathrm{mm}$ long and $26 \mathrm{~mm}$ wide; maximum width is achieved between one quarter and one half of the cone length. The cone tapers gently from its mid point to an obtuse apex, length/width ratio is 3.0. The cone axis is exposed only in the lower half where it is $4 \mathrm{~mm}$ thick (Fig. 4A-C). Pedicels are not clearly visible and therefore cannot be described in detail. However, pedicel overprint on the cone surface indicates that they are attached to the cone axis at an angle of about $60^{\circ}$. The pedicels are between 7 and $8 \mathrm{~mm}$ long. Laminae are 

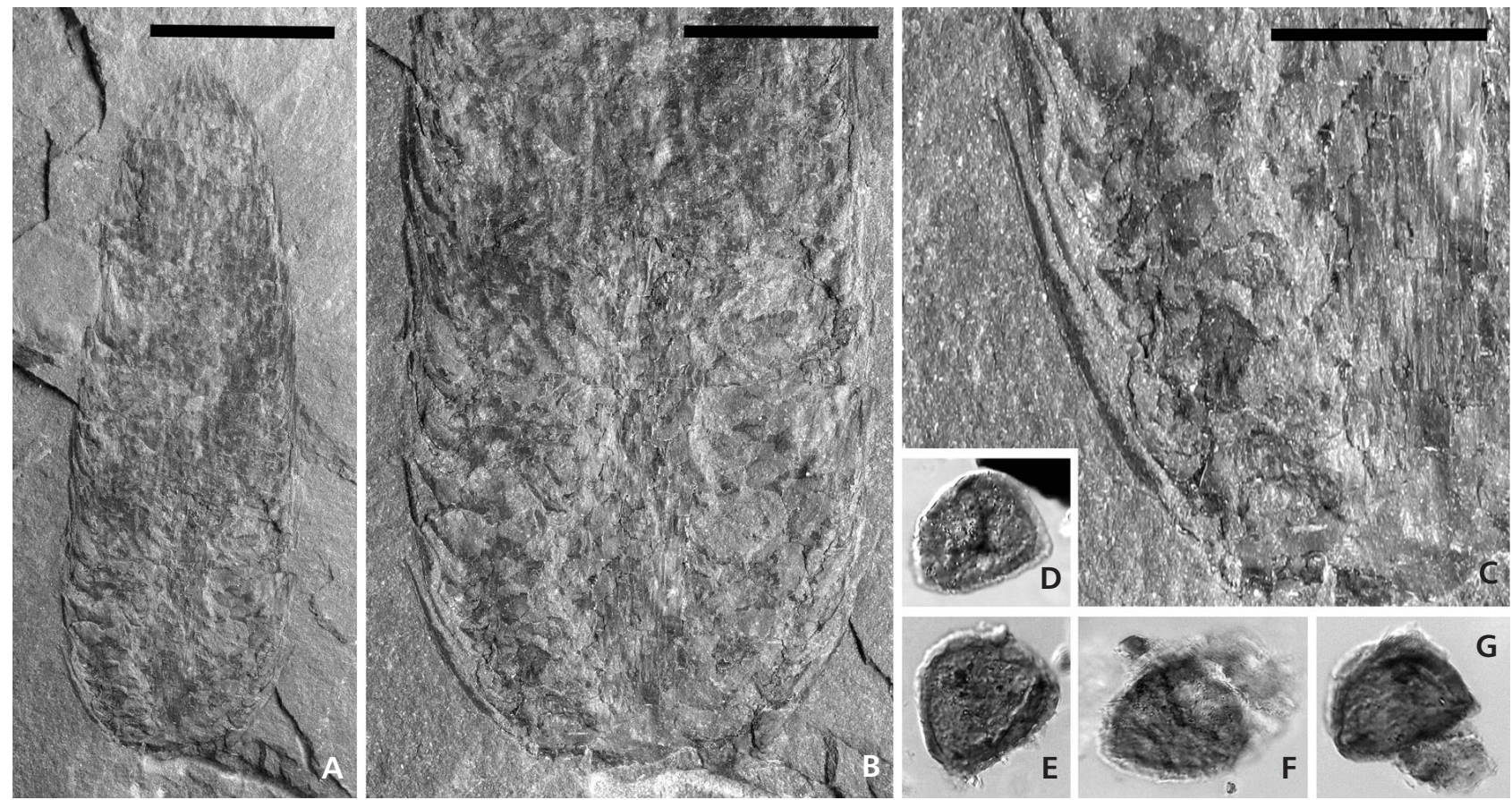

Figure 4. Lepidostrobus spinosus Kidston, 1888. A - cone of Lepidostrobus spinosus. Specimen BMNH 40587. Sunderland, Durham, North Cumberland-Durham Coalfield. Coal Measures, Westphalian, scale bar $20 \mathrm{~mm}$. $\bullet$ B - detail of lower part of the cone, scale bar $10 \mathrm{~mm}$. $\bullet$ C - detail of sporophylls, scale bar $5 \mathrm{~mm}$. $\bullet \mathrm{D}-\mathrm{G}$ - in situ trilete cingulizonate lycospores with relatively narrow cingulum and narrow zona, all $\times 500$.

triangular with gently concave entire margins, about $10 \mathrm{~mm}$ long with very fine longitudinal striations.

Spores: These are subtriangular to subcircular trilete microspores 29 (33.8) $35 \mu \mathrm{m}$ in diameter. The laesurae is simple, extending to the outer margin of the central body. Cingulum is 2.0 (2.7) $3.9 \mu \mathrm{m}$ wide and developes as a dark thickened ring on the outer margin of the central body. Zona may be sometimes perforated and usually is laevigate to finely scabrate and 1.3 (2.2) $3.3 \mu \mathrm{m}$ wide. Proximal and distal surfaces are irregularly scabrate, finely or densely microgranulate, microverrucate or microspinate. The number of sculpture elements is higher on the distal than on the proximal surface. Isolated microspores belong to the subgroup of cingulizonate lycospores with relatively narrow cingulum and narrow zona (Bek \& Opluštil 2006) and can be correlated to the dispersed miospore species Lycospora subjuga, L. brevijuga, L. triangulata, L. microgranulata or L. contacta.

Parent plant of L. spinosus is not known. One of the cones from the Kidston type specimen (No. 1548) has a $4.5 \mathrm{~mm}$ wide decorticated stalk, which may represent a leafy shoot of the parent plant.

Comparisons and discussion. - Lepidostrobus spinosus is a rarely occurring lepidodendrid cone species. In the Kidston collection, there are only three specimens identified as L. spinosus: No. 371 (Asturian/Cantabrian, Somerset Coalfield) and Nos 712 and 1548 (Langsettian to Duckmantian,
Kilmarnock Coalfield). Examination of these specimens, however, indicates that Kidston most probably conflated two different species. Specimen No. 371 is very similar to Lepidostrobus obovatus borne on Lepidodendron mannabachense, which is a common plant species of the middle Namurian to the late Westphalian. This re-interpretation is further corroborated by the presence of several centimetres long grass-like leaves typical of leafy shoots of the parent plant with which L. obovatus is often found in organic connection. The remaining Kidston specimens of L. spinosus from Kilmarnock (Nos 712 and 1548) are most probably the same species, and therefore can be compared with the specimens described here. Specimen No. 712 contains three complete or nearly complete cones of the same shape as the cone in BMNH 40587. These cones are 70-87 mm long and between 21 and $28 \mathrm{~mm}$ wide with a $4 \mathrm{~mm}$ broad cone axis. Specimen No. 1548 is a large slab containing three complete cones and four cone fragments. The cones are about $90 \mathrm{~mm}$ long, and their width varies between 23 and $30 \mathrm{~mm}$. The axis is also of comparable width to BMNH 40587. The sample taken from cones of this Kidston specimen (No. 1548) yielded in situ spores with relatively narrow cingulum and narrow zona (Fig. 4D-G), similar to the spores obtained from the cone of L. spinosus described here. This is further corroborating evidence that both belong to the same species.

Comparison with similar cones from coalfields outside the British Isles proved that the specimen of L. spinosus de- 
scribed here yielded spores similar to Hagemann's (1966) specimen of Lepidostrobus sp. D from the Campine Basin in Belgium. However, Hagemann's specimen differs in the shape of the laminae, which are longer and possess less concave margins. L. spinosus cones also appear to be oval, whereas the preserved part of the Belgian specimen is clearly a cylindrical cone. Thomas (1965) reported in situ lycospores isolated from an adpression specimen of L. spinosus. These microspores belong to the group of cingulizonate lycospores with relatively narrow cingulum and narrow zona (i.e. similar to those isolated from specimens described here and also classified as L. spinosus).

L. spinosus can also be compared with similar lepidodendrid cone species, especially with L. obovatus and with the specimens described here as L. boltonensis and L. huttonii. L. obovatus is a cone of comparable size and similar oval outline with maximum width at its mid point. Its pedicels are, however, attached perpendicularly to the cone axis compared with those of L. spinosus that attach at an angle of around $60^{\circ}$. Moreover, both species can be clearly distinguished by their in situ spores. Those of L. obovatus are compared with Lycospora loganii (i.e. lycospores with narrow cingulum and wide zona). The similar species L. boltonensis differs from L. spinosus only in cone morphology, especially its slender axis, apparently cylindrical shape, and characteristic slightly pointed apex. It is more difficult to distinguish L. spinosus from L. huttonii. Both species produced very similar spores, and the cone morphology also appears to be very similar. The only difference appears to be the position of the maximum width; in L. huttonii maximum width is achieved at the mid-point of the cone length, whereas in L. spinosus it is below this point and toward the base.

In situ spores isolated from the specimen of Lepidostrobus spinosus described here are comparable to spores obtained from several Czech cone species (Lepidostrobus nemejcii, L. sp. C and L. sp. D) already discussed in the sections related to L. boltonensis and L. huttonii. Unfortunately, none of these Czech cone species are comparable with the British L. spinosus. L. nemejcii is an obviously much larger cone; the largest (and still incomplete) specimen is $320 \mathrm{~mm}$ long and $45 \mathrm{~mm}$ wide, with a cone axis about $9 \mathrm{~mm}$ wide. $L$. sp. D is cylindrical in shape with a rounded apex, and is also evidently a different cone. The only specimen is $125 \mathrm{~mm}$ long and only $20 \mathrm{~mm}$ wide, and is incomplete. The most similar Czech cone species is $L$. sp. C. However, the only known specimen is a $70 \mathrm{~mm}$ long fragment of a medium-sized cone, the shape of which is impossible to determine. This specimen is about $45 \mathrm{~mm}$ wide and has an $8.5 \mathrm{~mm}$ wide axis.

Willard (1989b) described a roughly similar type of cingulizonate lycospores with relatively narrow cingulum and narrow zona from two adpression cone species, Lepidostrobus variabilis (Langsettian-Bolsovian of the
Illinois and Appalachian basins) and L. praelongus Lesquereux (Asturian of Pennsylvania). Willard (1989b) compared lycospores isolated from both cone species to the dispersed spore species Lycospora torquifer. Another similar type of in situ spores of the Lycospora punctata-type were described by Willard (1989b) from adpression specimens of Lepidostrobus cf. squarrosus from the Asturian or Cantabrian of Forest of Dean, England. Except for L. cf. squarrosus, all of Willard's (1989b) above-mentioned species represent morphologically different cones. Her L. cf. squarrosus is an oval shaped cone up to $87 \mathrm{~mm}$ long, with maximum width at its mid point. All of the specimens of L. spinosus, in contrast, achieve their maximum width in the first quarter of the length above the base.

\section{Lepidostrobus cf. obovatus (Němejc, 1947) Bek \& Opluštil, 2004}

Figure 5

Material. - Specimen BMNH V.65201b.

Locality. - Dudley, Worcestershire.

Stratigraphy. - Coal Measures, ?Duckmantian, Westphalian.

Note on the locality. - The specimen most probably comes from the Coseley nodule flora locality; Coseley in suburb of Dudley. The locality is of Duckmantian age (Cleal, written comm.).

Description. - Cone: This specimen is a rusty-brown ironstone nodule containing two fragments of lepidodendrid cones. The larger fragment is about $100 \mathrm{~mm}$ long and is the middle part of a cone with broken base and apex. The smaller fragment is a $40 \mathrm{~mm}$ long apical part of a cone most probably detached from the larger cone fragment. The cone is split longitudinally, partly along the cone surface and partly along the cone axis. The combined length of the two fragments is about $150 \mathrm{~mm}$, thus it can be assumed that this is the length of the complete cone. The cone is about $20 \mathrm{~mm}$ wide without distal laminae (axis and sporangia-bearing part of sporophylls) and $25 \mathrm{~mm}$ wide including distal laminae. The cone is widest near its mid-point, from where it very slowly tapers to the base and apex. Cone axis is 2.5 $\mathrm{mm}$ thick. Pedicels are inserted perpendicular to the cone axis, but near the base they are slightly downward pointing. The pedicels are up to $8 \mathrm{~mm}$ long in the middle part of the cone.

The height of pedicels increases from about $0.5 \mathrm{~mm}$ near the cone axis to about $1 \mathrm{~mm}$ at a distal end. The keel is not prominent; the heel is about $1 \mathrm{~mm}$ long. Neighbouring pedicels are about $2.2 \mathrm{~mm}$ apart. Sporangia are 

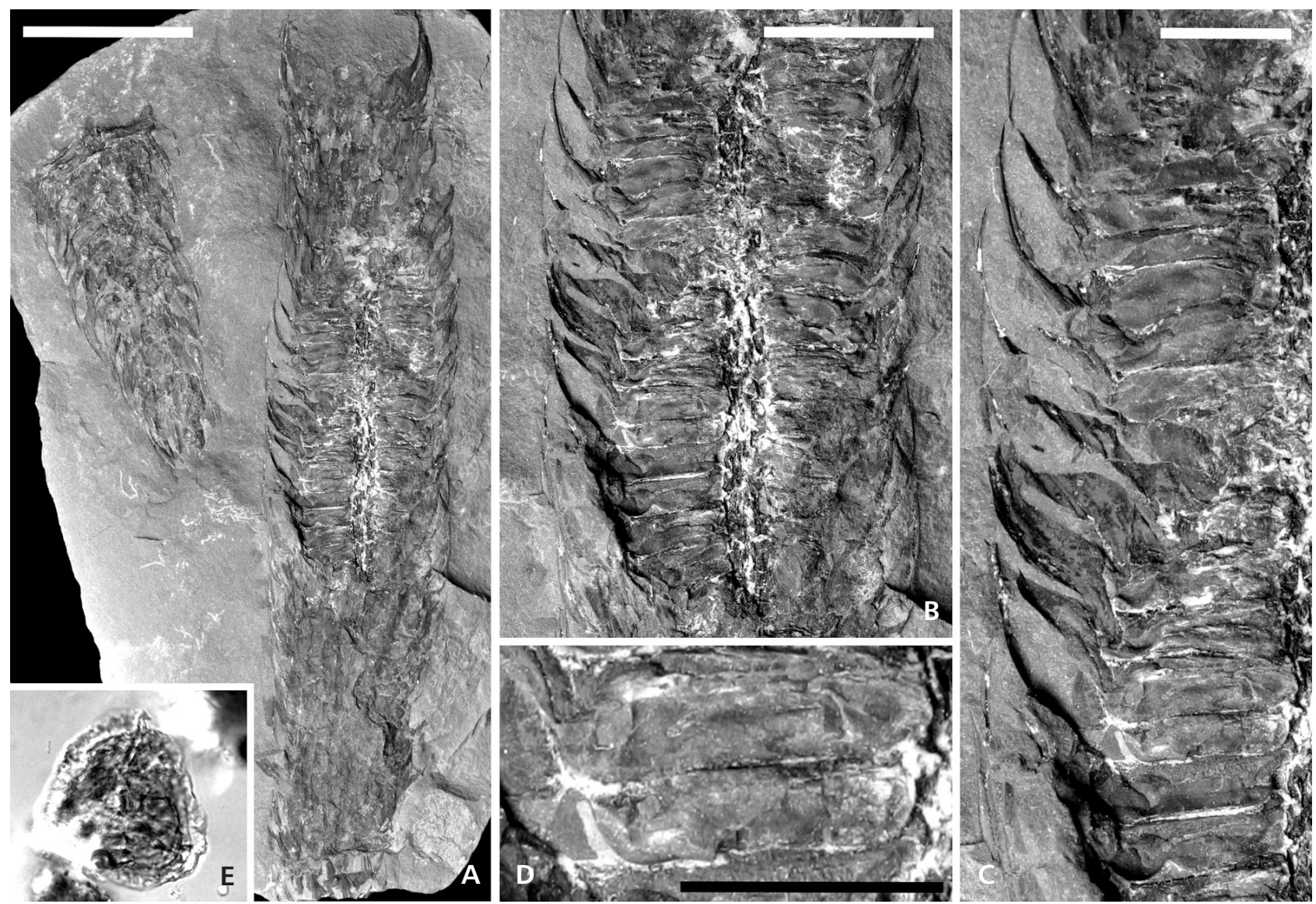

Figure 5. Lepidostrobus cf. obovatus (Němejc, 1947) Bek \& Opluštil, 2004. • A - Lepidostrobus cf. obovatus. Specimen BMNH V.65201b. Dudley, Worcestershire. Coal Measures, Westphalian, scale bar $20 \mathrm{~mm}$. $\bullet$ B - detail of middle part of the cone, scale bar $10 \mathrm{~mm}$. $\bullet$ C - detail of sporophylls with laminae, scale bar $5 \mathrm{~mm}$. $\bullet \mathrm{D}$ - detail of pedicels with sporangia, scale bar $5 \mathrm{~mm}$. $\bullet$ E - in situ trilete cingulizonate lycospore with relatively narrow cingulum and wide zona, $\times 500$.

oval; in the middle part of cone they are about $7.5 \mathrm{~mm}$ long and $1.8 \mathrm{~mm}$ high (Fig. 5C, D). Distal laminae are triangular with entire margins and midrib. Distal laminae are $9-10 \mathrm{~mm}$ long and 3.5 to $4 \mathrm{~mm}$ wide at the base, bent arch-like to the apex, and adpressed to the cone (Fig. 5C). They are concave in the lower one third of the length.

Spores: These are trilete microspores with circular to subtriangular amb, outline is smooth or slightly undulate; the size ranges from 38 (41.2) $43.0 \mu \mathrm{m}$. The laesurae is simple, extending to the outer margin of central body, sometimes with labrum $1-3 \mu \mathrm{m}$ large. The cingulum is $1.6(1.8)$ $2.0 \mu \mathrm{m}$ wide. Zona 3.0 (4.2) $5.6 \mu \mathrm{m}$ wide, is laevigate, punctate or sometimes can be perforated. The sculpture of the proximal and distal parts of zona is laevigate, irregularly scabrate or pitted. The sculpture of the proximal surface is laevigate to finely scabrate; the distal surface is finely microgranulate (Fig. 5E).

Isolated microspores belong to the subgroup of cingulizonate lycospores with relatively narrow cingulum and wide zona (Bek \& Opluštil 2006). The width of the zona is more than $4 \mu \mathrm{m}$. For example, dispersed species Lycospora loganii, L. pellucida, L. micropapillata, L. micrograna, L. intermedia, L. pseudoannulata and L. perforata belong to this subgroup. Some specimens can possess more or less prominent perforations of the zona (like L. perforata, L. pseudoannulata).

Comparisons and discussion. - This cone strongly resembles Lepidostrobus obovatus and is also similar to L. huttonii. In its type area (the basins of central and western Bohemia, Czech Republic), L. obovatus belongs to common lepidodendrid fructifications and is well-known, including both in situ spores and parent plant, Lepidodendron mannabachense (= L. obovatum). Both Bohemian cones and the British specimen described here are of the same cone morphology, including the sporophylls and their characteristic perpendicular insertion to the cone axis. They possess a similar type of lycospores and the parent plant, Lepidodendron mannebachense, is a common species of the British coalfields. The only difference is the larger size of the British specimen, especially its length. The largest Czech 
specimens are about $100 \mathrm{~mm}$ long, whereas the length of the British specimen is estimated to be about $150 \mathrm{~mm}$. This difference might be explained by ecological conditions, but could also indicate a different species. The larger size of the British specimen compared with the Czech cones could, in part, be explained by preservation in a siderite nodule. This style of preservation can prevent plant remains from shrinkage, which can reduce size by up to $13 \%$ during fossilisation (Cleal \& Shute 2007).

However, because all other features are comparable and fit within the range of variability of Lepidostrobus obovatus from the central and western Bohemia, and because the parent plant is also known from the British coalfields, specimen No. BMNH V.65201b is assigned to this species. Comparable in situ lycospores were also isolated from other Czech adpression species L. sp. A and L. sp. B (Bek \& Opluštil 2006). Lepidostrobus sp. A is a fragment of cone of similar width which differs significantly in having an $8 \mathrm{~mm}$ thick axis compared to the $2.5 \mathrm{~mm}$ axis of the described specimen of Lepidostrobus obovatus. Both species also differ in their stratigraphic distribution: Lepidostrobus sp. A is of middle Stephanian age compared to the lower Westphalian age of the British specimen. Lepidostrobus sp. B is of similar age (Bolsovian), however, it is too poorly preserved for reliable comparison with the British specimen. Both specimens correspond in size but the sporophylls of $L$. $\mathrm{sp}$. B are shorter. Also the cone axis is wider in the Czech specimen.

Very similar types of in situ lycospores were mentioned by Hagemann (1966) from German adpression species of Lepidostrobus sp. C from the Duckmantian strata of the Ruhr Basin. Unfortunately this specimen is a cone fragment that is only about $2 \mathrm{~cm}$ long. It is split along the surface thus excluding reliable comparison with the specimen described here. Willard (1989b) obtained roughly comparable lycospores from American adpressed specimens of $L$. praelongus and L. variabilis. The former is a large lycopsid cone about $200 \mathrm{~mm}$ long with a thick axis, whereas the latter is about $185 \mathrm{~mm}$ long, oval and with short laminae about 10-11 mm long. Except for the length, the morphology of L. variabilis of Willard (1989b) is similar to the specimen described in this paper, and it is possible that both are the same species. Nevertheless, her specimen is not a type specimen and therefore we do not refer our specimen to this species.

This type of in situ lycospore is known also from American permineralized species L. fayettevillense Taylor \& Eggert described by Taylor \& Eggert (1968) and L. oldhamius Williamson (associated with Lepidofloyos harcourtii-type of parent plant) published by Willard (1989a). Thomas (1988) described roughly similar lycospores from permineralized specimens of Lepidostrobus binneyanus Arber.
Genus Flemingites (Carruthers, 1865) Brack-Hanes \& Thomas, 1983

Type species. - Flemingites gracilis (Carruthers, 1865) Brack-Hanes \& Thomas, 1983.

\section{Flemingites cf. russelianus (Binney, 1871) Brack-Hanes \& Thomas, 1983}

Figure 6

Material. - Specimen No. BMNH V.5888.

Locality. - Devonside, Tillicoultry, Clackmannan.

Stratigraphy. - Coal Measures, Westphalian.

Description. - Cone and parent plant: The specimen contains an incomplete cone associated with lepidodendrid leafy shoots and branches preserved in a mudstone slab. The cone apex and right margin of the cone are missing. The cone is preserved as an adpression split longitudinally along the surface and covered by imbricated distal laminae. No details of the cone axis and pedicel arrangement can be observed.

The cone is cylindrical tapering rapidly only above the obtuse base. The cone fragment is $110 \mathrm{~mm}$ long, but the original length is difficult to estimate because there is no indication of any tapering at the preserved upper part of the cone (Fig. 6A, B). The maximum preserved width is $18.5 \mathrm{~mm}$, which must be very close to original width of the cone. Sporophyll laminae are lanceolate with entire margins. They are 10-11 mm long and about $2.5 \mathrm{~mm}$ wide at or near the base. Sterile fragments associated with the cone represent some thin leafy shoots, but mostly leafy branches with well-preserved leaf cushions. The $20 \mathrm{~mm}$ thick branch has elongated rhomboidal leaf cushions, which are between 7 and $8 \mathrm{~mm}$ long and about $3 \mathrm{~mm}$ wide. The widest part is situated between the middle and upper two thirds of the cushion. Leaf cushions are longitudinally asymmetrical, but some of them can be nearly symmetrical (Fig. 6C). They have acute lower and upper angles and rounded lateral angles. They are smooth and quite flat, or raised only slightly in the apical part. In longitudinal section, the keel is straight, very slightly raised, and runs through the whole length of the cushion. Infrafoliar parichnos is absent. True leaf scars are also absent because the leaves are still attached to the leaf cushions. Instead, very small punctiform false leaf scars appear near the cushion apex. The leaves are lanceolate and about $25 \mathrm{~mm}$ long and about $2 \mathrm{~mm}$ wide. They are bent in a slightly S-like shape in the lower part and curved in an arch in the upper part. The younger leafy shoots have leaves that are only about $12 \mathrm{~mm}$ long and $1 \mathrm{~mm}$ wide near the base. The characteristics of leaf cushions bearing S-bend leaves resemble those of Lepidodendron acutum and possibly also 

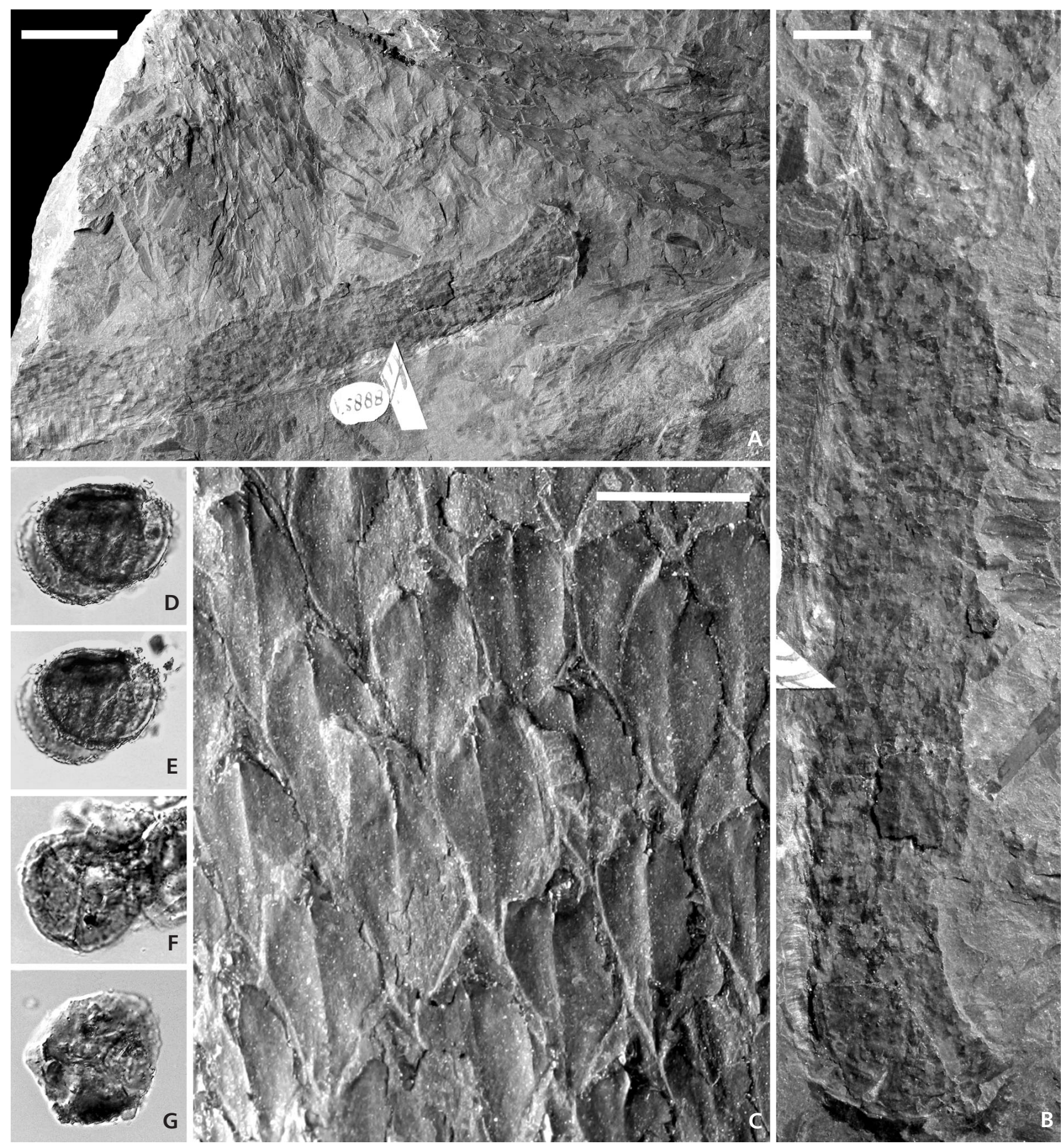

Figure 6. Flemingites cf. russelianus (Binney, 1871) Brack-Hanes \& Thomas, 1983. • A - cone of Flemingites cf. russelianus with leafy shoots and branches of Lepidodendron acutum - L. simile-type. Specimen BMNH V.5888. Devonside, Tillicoultry, Clackmannan, Scotland. Coal Measures, Westphalian, scale bar $15 \mathrm{~mm}$. $\bullet \mathrm{B}$ - detail of cone, scale bar $5 \mathrm{~mm} . \bullet \mathrm{C}$ - detail of leaf cushions of associated branches with false leaf scar, scale bar $5 \mathrm{~mm}$. - D-G - in situ trilete cingulate lycospores with relatively narrow cingulum and prominent microspinate sculpture of the proximal surface, all $\times 500$.

those of Lepidodendron simile sensu Němejc (1947), which is a very similar species. Both species are very difficult to distinguish based on small fragments only. L. acutum differs in having generally larger and broader leaves and small leafy shoots compared to $L$. simile. Unfortunately, the branch re- mains of this specimen are not sufficiently complete for more reliable identification. There is also a fragment of a poorly preserved branch of Lepidophloios sp. This, however, has nothing in common with the cone since Flemingites cones were not borne on Lepidophloios. 
Spores: These are circular to subtriangular trilete microspores 26 (32.6) $37 \mu \mathrm{m}$ in diameter. Their outline is denticulate. The laesurae is simple, reaching to the equator. The cingulum is 0.8 (1.3) $2.0 \mu \mathrm{m}$ wide. The proximal surface is laevigate; the distal surface is densely microspinate, and the exine thin, sometimes with narrow secondary folds. An inner body is sometimes visible.

Isolated microspores (Fig. 6D-G) belong to the subgroup of cingulate lycospores, which have a narrow cingulum with a densely microspinate distal surface (Bek \& Opluštil 2006). These are comparable to the dispersed spore species Lycospora orbicula Potonié \& Kremp.

Remarks. - Chaloner (1953a) described the same type of in situ microspores and isolated megaspores compared to the dispersed spore species Lagenicula horrida Zerndt from several specimens of Lepidostrobus dubius Binney (two specimens from the Sedgwick Museum, Cambridge; three specimens from the Kidston's collection, British Geological Survey, Keyworth; one from the Natural History Museum, London and one from the Royal Holloway College, University of London). The authors were unable to isolate megaspores from specimen BMNH V.5888 due to the tiny amount of sample allowed for the maceration. For description, measurement of in situ megaspores of Flemingites russelianus and discussion, see Lepidostrobus russelianus of Chaloner (1953a, pp. 277-283).

Parent plant. - The cone is associated with two types of branches, which can be assigned to Lepidophloios cf. acerosus and to Lepidodendron acutum Sternberg - L. simile sensu Němejc (1947). The former is represented only by a small and poorly preserved fragment that is unlikely to be connected with the cone because Lepidophloios bears monosporangiate cones assigned to Lepidostrobus if microsporangiate, or to Lepidocarpon if megasporangiate (Bateman et al. 1992). The latter species, Lepidodendron acutum or L. simile (cannot be distinguished from the preserved remains) are often associated with this type of small to medium size cylindrical cone that bears both microspores and megaspores (e.g., Chaloner 1953a). We consider these to be part of the parent plant of the cone.

Comparisons and discussion. - According to Chaloner (1953a) cones associated with Lepidodendron acutum belong to Lepidostrobus russelianus (Binney) Chaloner (now Flemingites russelianus - for explanation see Crookall 1966 and Brack-Hanes \& Thomas 1983) and those associated with Lepidodendron simile Kidston belong to Lepidostrobus dubius, now assigned to Flemingites gracilis. Therefore, this cone was first compared with these species and later with some other similar Flemingites fructifications (F. olryi Zeiller).

Morphologically, this cone best resembles F. russel- lianus and F. gracilis (formerly Lepidostrobus dubius) in being narrow and more or less cylindrical. According to Crookall's (1966) description, except for the generally smaller habit of $F$. russellianus (up to $150 \mathrm{~mm}$ long and $20 \mathrm{~mm}$ wide) in comparison to $F$. dubius (up to $250 \mathrm{~mm}$ long and $18 \mathrm{~mm}$ wide), there is no significant morphological difference between these species. Not surprisingly, as late as 1953, Chaloner, who macerated both of Binney's (1871) original specimens of $F$. russellianus, recorded different in situ megaspores in each, which were referred to Triletes horridus Nowak \& Zerndt and T. rugosus Loose, i.e. Lagenicula horrida Zerndt and Lagenoisporites rugosus (Loose) Potonié \& Kremp. The specimen that provided Lagenicula horrida megaspores (Pl IX, Fig. 2) was selected by Chaloner as the lectotype for his emended description of Lepidostrobus dubius, now Flemingites gracilis. Chaloner (1953a) also stated that both cone species could be distinguished in having different parent plants: F. russellianus was borne on Lepidodendron acutum, whereas $F$. gracilis was borne on Lepidodendron simile. Megaspores and parent plants thus remain the main criterion for separating Flemingites gracilis and F. russelianus. Specimen BMNH V.5888 described here provided only microspores of Lycospora orbicula-type, which indicate a position within the genus Flemingites. However, megaspores important for determination at specific level have not been obtained. Therefore, only the association with the parent plant can be used to support the determination. Unfortunately, as explained above, the remains of parent plant are not sufficiently well preserved for reliable determination (i.e. L. acutum or L. simile). The authors lean towards an affinity with L. acutum, which means that fructification should correspond to Flemingites russelianus.

Another species, $F$. olryi, is evidently a different species characterised by smaller and gently tapering cones, about $100 \mathrm{~mm}$ long and about $10 \mathrm{~mm}$ wide. The spores of the holotype, which comes from Northern France, are unknown. However, Chaloner (1953a) isolated megaspores of the Lagenoisporites rugosus-type and microspores of the Lycospora orbicula-type from some British specimens identified by Kidston as Lepidostrobus (= Flemingites) olryi Zeiller.

In the coalfields of central and western Bohemia, Czech Republic, cones similar to the specimen described here occur in the middle Westphalian strata and are also associated with Lepidodendron acutum and L. simile. However, there is no published systematic study of Flemingites from the Czech Carboniferous.

\section{Genus Sigillariostrobus Schimper, 1870 ex Feistman- tel, 1871}

Type species. - Sigillariostrobus bifidus Geinitz, E. 1873. 
Stanislav Opluštil \& Jiří Bek • Some Pennsylvanian arborescent lycopsid cones and their microspores from the British coalfields

Table 4. Review of selected Flemingites cones and their in situ micro- and megaspores

\begin{tabular}{llll}
\hline cone species & microspores & megaspores & references \\
\hline Flemingites allatonensis & - & Lagenicula crassiaculeata & Chaloner 1953b \\
Flemingites diversus & Lycospora orbicula & Lagenoisporites rugosus & Felix 1954, Courvoisier \& Philips 1975 \\
Flemingites gracilis & Lycospora orbicula & Lagenicula horrida & Chaloner 1953b, Brack-Hanes \& Thomas 1983 \\
Flemingites noei & $?$ & Lagenicula & Felix 1954, Mathews 1940 \\
Flemingites olryi & Lycospora orbicula & Lagenoisporites rugosus & Chaloner 1953b \\
Flemingites russelianus & Lycospora orbicula & Lagenoisporites rugosus & Chaloner 1953b \\
Flemingites schopfii & Lycospora & Lagenicula horrida & Brack 1970 \\
Flemingites scottii & Lycospora & Lagenicula subpilosa f. major & Chaloner 1953b \\
Lepidostrobus sp. C & Lycospora orbicula & Lagenoisporites rugosus & Hagemann 1966 \\
Lepidostrobus sp. U & Lycospora orbicula & - & Balbach 1966 \\
Flemingites lycopoditis & Lycospora orbicula & Lagenoisporites rugosus & Drábek 1967, Bek 1998, Bek \& Opluštil 1998 \\
\hline
\end{tabular}

Sigillariostrobus acicularis sp. nov.

Figure 7

Material. - Specimen No. BMNH V.65200.
Locality. - Ashton-under-Lyme, Lancashire Coalfield.

Stratigraphy. - Middle Coal Measures, Duckmantian.

Etymology. - Name derived according to the acicular shape of sporophylls.

Diagnosis. - Cone cylindrical, about $130 \mathrm{~mm}$ long and 22-24 mm wide including laminae. Peduncle 3 to $5 \mathrm{~mm}$ wide and more than $25 \mathrm{~mm}$ long. Cone axis $4.5 \mathrm{~mm}$ wide. Sporophylls in alternate whorls, internode longitudinally ribbed. Sporophylls 20 to $25 \mathrm{~mm}$ long and 4 to $5 \mathrm{~mm}$ wide near the base, acicular-lanceolate in shape with rhomboidal base and prolonged acute apex, locally with cilia. Trilete microspores with circular to oval amb. Equatorial thickening. Distal surface microgranulate to microspinate, proximal surface scabrate to smooth.

Description. - Cone: The specimen preserved in a mudstone is a small cylindrical strobilus with a blunt apex. It is about $130 \mathrm{~mm}$ long and 22-24 mm wide and borne on a $25 \mathrm{~mm}$ long (not complete) and 3 to $5 \mathrm{~mm}$ wide peduncle (Fig. 7A, B). The cone axis is $4.5 \mathrm{~mm}$ wide. Sporophylls are arranged into alternate whorls. Internodes are longitudinally ribbed. Sporophylls possess a single central vein about 20 to $25 \mathrm{~mm}$ long and about 4 to $5 \mathrm{~mm}$ wide near the base. They are acicular-lanceolate with rhomboidal base and prolonged acute apex (Fig. 7C). Margins in the upper two thirds are almost entirely slightly concave, and in the apical part they bear a few cilia (Fig. 7C1-3). However, due to vagaries in preservation this can only be seen on some sporophylls.

Spores: These are circular to oval trilete microspores
62 (72.9) $86 \mu \mathrm{m}$ in diameter. In equatorial view their shape is more or less lenticular with prominent thickening 4.8 (6.3) $7.4 \mu \mathrm{m}$ in diameter at the equator (Figs 7D-G). The laesurae is simple, extending nearly to amb, and not always visible. The distal surface is microgranulate to microspinate, and the proximal surface is typically almost smooth or very finely scabrate. Exine in the region of crassitudinous thickening is darker in colour than in polar region. The equatorial thickening extends towards the poles for a distance 5-10 $\mu \mathrm{m}$.

Isolated microspores can be compared to the dispersed spore species Crassispora kosankei (Potonié \& Kremp) Bharadwaj.

Comparisons and discussion. - The specimen described above (BMNH V.65200) was compared first with the British Sigillariostrobus species, as well as with species from other European coalfields. Crookall (1964) reported only Sigillariostrobus nobilis Zeiller, S. rhombibracteatus Kidston and S. ciliatus Kidston from the British Coal Measures, whereas Chaloner (1953b) synonymised S. ciliatus with $S$. rhombibracteatus based on identical spores and described only two species from the British coalfields. There are, however, several other species from similar stratigraphic levels known from other European coalfields to which this specimen could be compared (for overview see Amerom \& Gaipl 1995).

When comparing the London specimen BMNH V.65200, we took into account not only cone morphology but also stratigraphic range of species and their spores. We consider the character of spores as an important part of the species diagnosis, and therefore even morphologically similar cones with different spores are considered different species. This view is at odds with that of Amerom \& Gaipl (1995) who would place Sigillariostrobus cones with different spores in the same species. For example, cones of $S$. rhombibracteatus, one of the most common species, yield both Crassispora-type microspores and Tuberculati- 
Table 5. The diameter and classification of sigillarian permineralized (P) and adpression (A) in situ micro- and megaspores and their parent cones

\begin{tabular}{|c|c|c|c|}
\hline cone species & $\begin{array}{l}\text { diameter of spores } \\
(\mu \mathrm{m})\end{array}$ & classification of in situ spores & references \\
\hline Mazocarpon bensonii $(\mathrm{P})$ & $\begin{array}{c}1200-1500 \\
48-54\end{array}$ & Laevigatisporites reinschii Crassispora & Feng \& Rothwell 1989, Pigg 1983 \\
\hline Mazocarpon oedipternum f. megalophorum (P) & 1600 & Laevigatisporites reinschii, L. glabratus & Chaloner 1967, Schopf 1941 \\
\hline Megalocarpon oedipternum f. microphorum (P) & $45-60$ & Crassispora kosankei & $\begin{array}{l}\text { Courvoisier \& Phillips } 1975, \\
\text { Schopf 1941, Chaloner } 1967\end{array}$ \\
\hline Mazocarpon shorense $(\mathrm{P})$ & $1200-1900$ & Tuberculatisporites & Chaloner 1967 \\
\hline Sigillariostrobus souchii (A) & 2500 & Tuberculatisporites mamillarius & Chaloner 1967 \\
\hline Sigillariostrobus czarnockii (A) & $\begin{array}{c}1200-1700 \\
50-70\end{array}$ & Laevigatisporites Crassispora & Bocheński 1939, Chaloner 1967 \\
\hline Sigillariosporus leiosporous (A) & 2000 & Laevigatisporites glabratus & Abbott 1963 \\
\hline Sigillariostrobus quandangularis (A) & $\begin{array}{c}? \\
55\end{array}$ & $\begin{array}{l}\text { Tuberculatisporites mamillarius } \\
\text { Crassispora? }\end{array}$ & Wood 1957, Chaloner 1967 \\
\hline Sigillariostrobus rhombibracteatus (A) & $\begin{array}{l}920-1200 \\
55\end{array}$ & $\begin{array}{l}\text { Tuberculatisporites mamillarius } \\
\text { Crassispora }\end{array}$ & $\begin{array}{l}\text { Bocheński 1939, Remy \& } \\
\text { Rettschlag 1954, Chaloner 1953a }\end{array}$ \\
\hline Sigillariostrobus tieghemii (A) & 1500 & Laevigatisporites & Carpentier 1933 \\
\hline Sigillariostrobus souchii (A) & 2500 & Tuberculatisporites mamillarius & Zeiller 1886, Carpentier 1933 \\
\hline Sigillariostrobus goldenbergii (A) & $1452-1718$ & Tuberculatisporites mamillarius & Sen 1958 \\
\hline Sigillariostrobus angustus (A) & - & Crassispora kosankei & Amerom \& Gaipl 1995 \\
\hline Sigillariostrobus ciliatus & & Crassispora kosankei & herein \\
\hline
\end{tabular}

sporites mammilarius (Bartlett) Potonié \& Kremp megaspores. This is, however, not in agreement with the ICBN (McNeill et al. 2006).

In addition, sigillarian cones are almost always found without any connection to parent plants. Thus, it is not possible to state with certainty whether morphologically similar cones with megaspores or microspores were borne on the same parent plant. For this reason, we prefer separation of cones based not only on cone morphology, but also on whether they are microsporangiate or megasporangiate.

The species described here is characterised by very long and narrow bracts. Morphologically similar species with long and narrow bracts include $S$. gothanii Bode, S. strictus Zeiller, S. czarnockii Bocheński and S. prolifer Stockmans \& Willière. The only two known British species, Sigillariostrobus nobilis Zeiller and S. rhombibracteatus Kidston are clearly different. The cones of S. nobilis are more than $300 \mathrm{~mm}$ long and up to $65 \mathrm{~mm}$ wide, and thus differ significantly in size. The bracts are also short compared to their width and they are less cuspidate. Sigillariostrobus rhombibracteatus represents cones of comparable size to the specimen described here (BMNH V.65200), but appear to differ in having a shorter and less acicular part of the bract above the rhomboidal sporangium-bearing base. Excluding Moore's description, which is incorrect, spores of Sigillariostrobus rhombibracteatus were obtained and described by Bochenski (1939), Moore (1946), Chaloner (1953b) and Remy \& Rettschlag (1954). Bocheński (1939) obtained both megaspores of Tuberculatisporites and microspores of Crassispora-types from specimens in the Upper Sileasian Coal Basin. However, only Chaloner studied spores from some of Kidston's syntypes (both of $S$. ciliatus and S. rhombibracteatus), which provided only megaspores of Tuberculatisporites mamillarius. This indicates an apparent heterogeneity of the concept of Sigillariostrobus rhombibracteatus that will be discussed elsewhere. Here we focus on the Kidston syntypes of $S$. rhombibracteatus (incl. S. cilliatus) that we regard as a different species because they bear only megaspores. This conclusion is further supported by the morphological differences of the bracts as mentioned above.

The sigillarian cone described here (BMNH V.65200) displays a certain degree of similarity to the following species: S. gothanii Bode, S. strictus Zeiller, S. czarnockii Bocheński and $S$. prolifer Stockmans \& Willière from the western or central European coalfields. The holotype of $S$. strictus is associated with Sigillaria brardii Brongniart, which comes from the northern part of the Massif Central Basin (Decize) and is of Late Stephanian age. It is a cone fragment measuring about $120 \mathrm{~mm}$ in length, the body of which is about $15 \mathrm{~mm}$ wide $(25 \mathrm{~mm}$ wide including laminae). Sporophylls are narrow, about $230 \mathrm{~mm}$ long and $4 \mathrm{~mm}$ wide near the base. The laminar part of the sporophyll is acicular, about $15 \mathrm{~mm}$ long and gradually passes into a basal sporangium-bearing part. Sporophylls of $S$. strictus resemble those of $S$. acicularis, with the exception that the acicular part of the sporophyll of the new species is thinner (about $1 \mathrm{~mm}$ wide). Amerom \& Gaipl 

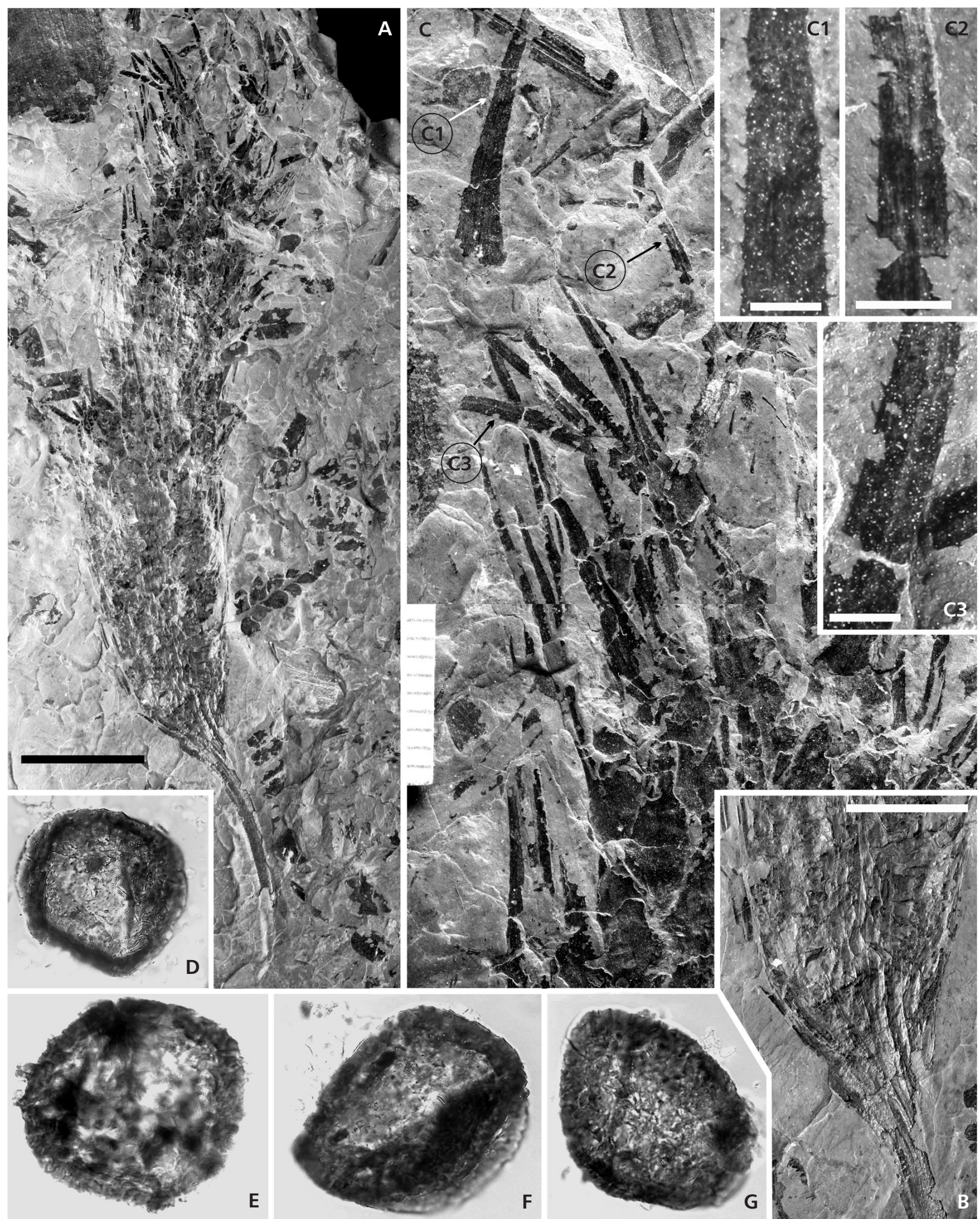

Figure 7. Sigillariostrobus acicularis n. sp. $\bullet$ A - cone of Sigillariostrobus acicularis n. sp. with peduncle. Specimen BMNH V.65200. Ashton-under-Lyme, Lancashire Coalfield. Middle Coal Measures, Duckmantian, scale bar $20 \mathrm{~mm}$. $\bullet$ B - detail of cone base with the transition to peduncle, scale bar $10 \mathrm{~mm}$. $\bullet \mathrm{C}$ - acicular sporophylls; C1-C3 - details of acicular sporophylls, all scale bars $1 \mathrm{~mm} . \bullet \mathrm{D}-\mathrm{G}-$ in situ trilete spores with crassitudous thickening of the Crassispora kosankei-type, all $\times 500$. 
(1995) also mentioned the megaspores assigned to Laevigatisporites glabratus (Zerndt) Potonié \& Kremp and compared these with Crassispora kosankei microspores of S. acicularis. Slight differences in cone morphology and completely different types of spores, as well as diffreneces in stratigraphic appearance led us to the conclusion that they represent different species. Two other similar species, S. czarnockii and S. gothanii, are a little larger (over $125 \mathrm{~mm}$ and over $150 \mathrm{~mm}$ in length, respectively), but their sporophylls are long and quite narrow, resembling those of $S$. acicularis. Nevertheless, these sporophylls differ in being still wider and having prominently ciliate margins. Both S. czarnockii and S. gothanii bear Laevigatosporites megaspores, but one cone of $S$. czarnockii also provided microspores of the Crassispora-type (Bocheński 1936, 1939). The remaining comparable species is $S$. prolifer from the Westphalian of Belgium. It is characterised by very narrow and $30 \mathrm{~mm}$ long sporophylls, which are very similar to those of $S$. acicularis. The cone of $S$. prolifer is also of comparable dimensions to $S$. acicularis, being only slightly longer (over $130 \mathrm{~mm}$ ) but of the same width. The only major difference seems to be the spores, which, in the Belgian species are only megaspores Laevigatisporites reinschii Ibrahim. This difference in spores is the only reason that we have assigned the cone described here to the new species $S$. acicularis. There are probably no similar forms in the Czech coalfields to which this new species could be compared.

\section{Discussion and comparison of described cones with the Czech species}

We have restricted our comparison of Czech and British tree lycopsid cones to species that are based not only on cone morphology, but also spores and, where possible, fragments of leafy branch. Only such broadly characterised species can provide a reliable basis for comparing fructifications among different Euramerican coalfields.

Based on in situ lycospores, the lepidodendrid cones described here can be subdivided into three groups. The first group consists of cingulizonate lycospores with relatively narrow cingulum and narrow zona (Bek \& Opluštil 2006). These lycospores were isolated from specimens BMNH V.12045A (Lepidostrobus boltonensis), BMNH 36465 (L. huttonii) and BMNH 40587 (L. spinosus). These specimens represent broadly similar cones that differ only in small morphological details. The parent plant is known only for specimen BMNH 36465, which is compared with Lepidophloios acerosus. Morphologically similar microspores were also isolated from the Czech adpression cone species Lepidostrobus sp. C and L. sp. D (Bek \& Opluštil 2006) and L. nemejcii (Bek \& Opluštil 2004). However, these Czech species differ in their cone morphology and cannot be assigned to any of the other species. The most similar is Lepidostrobus sp. C, which can be compared in part with Lepidostrobus spinosus. Unfortunately, L. sp. C is only a cone fragment and therefore a full comparison cannot be provided. The remaining Czech species are medium to large-sized cones, which appear to represent different species. A similar type of in situ lycospore was described by Hagemann (1966) in a cone adpression of L. sp. D from the Ruhr Basin, Germany. In situ lycospores isolated from permineralized (coal-balls) specimens of L. coulterii by Balbach (1966) and L. minor by Leisman \& Rivers (1974) are also of similar morphology.

The second group of in situ lycospores, characterised by relatively narrow cingulum and wide zona (Bek \& Opluštil 2006) is represented by specimen BMNH V.65201b only. Roughly similar in situ lycospores were isolated from Czech adpression species $L$. sp. A and $L$. sp. B (Bek \& Opluštil 2006) and also L. obovatus. L. sp. A is a middle Stephanian species (comparing to lower Westphalian age of the English species) which is a slightly larger cone with an apparently wider axis than the English specimen. However, the greatest similarity is between the specimen described here and L. obovatus, which represents both cones of comparable shape and sporophyll arrangement. The only difference is that the English specimen is a little larger and it has a more cylindrical shape.

The third subgroup comprises in situ cingulate lycospores with narrow cingulum and a densely microspinate distal surface (Bek \& Opluštil 2006). Spores of the Lycospora orbicula-type were isolated from a cone of specimen BMNH V.5888. These microspores were produced by cones of the genus Flemingites. In Britain similar microspores were obtained by Chaloner (1953a, 1967) from adpression specimens of Flemingites olryi and by Thomas (1965) from $F$. diversus and $F$. russelianus. In the Czech Republic spores of Lycospora orbicula-type were reported by Drábek (1967) from cones of Lepidostrobus brongniartii Goeppert (Bek 1998) and by Bek \& Opluštil (1998) from Lepidostrobus lycopoditis Feistmantel. The latter specimen is associated (not in organic connection) with Lepidodendron simile sensu Němejc (1947). A revision of the Czech Flemingites is in preparation, so the full comparison cannot yet be made. We can only confirm that different species of parent plants occur, including Lepidodendron simile and L. acutum. Also, various species of in situ megaspores (Lagenicula and Lagenoisporites) have been obtained, indicating the existence of several Flemingites species in the Czech coalfields.

Comparison of Czech and British sigillarian fructifications is practically impossible because no sigillarian cones have been described from the Czech coalfields. The cones of sigillarias are quite rare in the Czech coalfields, and in the collections of the National Museum in Prague there are only few undescribed specimens (Bek 
1998). Cones of the genus Sigillariostrobus are also relatively infrequent in the British coalfields (Crookall 1966). This is because mature cones disintegrated on dispersal into isolated sporophylls, whereas lepidodendrid cones remained intact. Moreover, sigillarian cones, when preserved, possess only very low variability, so comparatively few morphotaxa have been described. Known cone diversity does not reflect the species diversity in this group. There is a well-documented disparity between the numbers of Sigillaria species and their cone species recognised in the British coalfields. Crookall $(1964,1966)$ listed 54 species of sigillarias but only 3 species of Sigillariostrobus cones. It is possible that some Sigillariostrobus species represent several natural taxa. This state is impossible to improve even through the use of spores. Microspores isolated from these cones are all assigned to the dispersed microspore genus Crassispora Bharadwaj, the variability of which is also generally low. This suggests that cone and spore morphology in this group was much more conservative than in the case of lepidodendrid lycopsids.

\section{Summary and conclusions}

The tree lycopsid fructifications from the British Coal Measures (Pennsylvanian) described here are based on material selected from the collection of the Natural History $\mathrm{Mu}-$ seum, London. They provided a new set of complex data on cone morphology, in situ spores and, in some instances, also on leaf-bearing branches of the parent plants.

Six of the fifteen selected and sampled specimens yielded in situ microspores. These were described in detail and compared with similar forms from the Czech Republic and some other Euramerican coalfields. Cones of the genus Lepidostrobus were represented by four specimens that can be subdivided into two groups based on their spores. The first group includes cones assigned to Lepidostrobus boltonensis, L. huttoni and L. spinosus. These contain cingulizonate lycospores with relatively narrow cingulum and narrow zona that are comporable to the dispersed species Lycospora subjuga, L. brevijuga, L. triangulata, L. microgranulata or L. contacta.

The second group includes a single specimen identified as $L$. cf. obovatus, and has lycospores characterised by relatively narrow cingulum and wide zona. These are comparable to the dispersed species Lycospora loganii, $L$. pellucida, L. micropapillata, L. micrograna, L. intermedia, L. pseudoannulata and L. perforata.

Cones of the genus Flemingites are represented by the specimen identified as $F$. cf. russelianus. This cone yielded microspores identified as Lycospora orbicula.

Cones described here were compared with species from outside Britain and especially with those from Czech coalfields in central and western Bohemia. The comparison shows that Lepidostrobus cf. obovatus is common to both areas. It is likely that Flemingites cf. russelianus also occurs in the Czech coalfields, but this requires confirmation through revision of the Bohemian specimens. The remaining species either do not occur in the Czech coalfields, or their occurrence remains unproven. Lepidophloios acerosus described by Němejc (1947) from central and western Bohemia most likely represents a different species because its cones are very different from those described here (Lepidostrobus huttonii), and are found in organic connection with shoots of Lepidophloios acerosus. We have found several cylindrical cones up to $800 \mathrm{~mm}$ long attached to Lepidophloios acerosus sensu Němejc (1947) in the Radnice Basin in western Bohemia. The cone of L. acerosus from the British Coal Measures is much smaller, less than $100 \mathrm{~mm}$ long.

The only sigillarian cone was a specimen that is assigned to the new species Sigillariostrobus acicularis which yielded Crassispora kosankei microspores.

The study of tree lycopsid fructifications of the British Coal Measures combining palynological and macrophytopalaeontological methods should continue to provide further results necessary for the general comparison of lycopsid floras with other European coalfields.

This is the first attempt to compare and correlate Pennsylvanian lepidodendrid fructifications and their in situ spores from Great Britain and the Czech Republic. The results are preliminary because they are based on a small initial sample (only fifteen from about two hundreds stored in the Natural History Museum in London). Approximately $50 \%$ of the sampled specimens yielded valuable new data on in situ spores. Given the large numbers of cone specimens housed in museum collections in Europe and North America, we anticipate that these will provide an invaluable source of materials for refining the taxonomic framework of tree lycopods and for developing a better understanding of their stratigraphic and geographic ranges.

\section{Acknowledgement}

This research received support from the SYNTHESYS Project which is financed by European Community Research Infrastructure Action under the FP6 "Structuring the European Research Area" Programme. This support UK (GB-TAF - 1759) allowed the authors to visit and study the Carboniferous plant collection in the Natural History Museum, London. Maceration and some other work related to sample preparation were undertaken in the Department of Palaeobiology and Palaeoecology, Institute of Geology v.v.i. in Prague. We are also grateful for financial support from the Research programme (AVOZ30130516) of the Institute of Geology, v.v.i., Academy of Sciences of the Czech Republic, and project MSM 0021620855 of the Faculty of Science, Charles University. Special thanks to Peta Hayes and Paul Kenrick from the Natural History Museum, London, UK for help with access- 
ing specimens of Carboniferous plants in the Natural History Museum, London, UK. Paul Kenrick is also thanked for language correction of this article. The authors are also very grateful to Chris Cleal from the National Museums and Galleries of Wales, Cardiff and Jason Hilton from the University of Birmingham for their constructive comments for revision of the manuscript.

\section{References}

Аввотт, M.L. 1963. Lycopod fructifications from the Upper Freeport (No. 7) coal in southeastern Ohio. Palaeontographica B 112, 93-118.

AMEROM VAN, H.W.J. \& GAIPL, R. 1995. Ein bemerkenswerter Sigillariostrobus-fund (Sigillariostrobus angustus sp. nov.) aus dem Westfal B der Grube Anna, Alsdorf (NordrheinWestfalen, Deutschland). Palaeontographica B 235, 51-60.

ARBER, E.A.N. 1922-1924. Critical studies on coal measure plant impressions. Linnean Society Journal of Botany 46, $171-217$.

BALBACH, M.K. 1966. Microspore variation in Lepidostrobus and comparison with Lycospora. Micropaleontology 12, 334-342. DOI $10.2307 / 1484551$

BATEMAN, R.M. 1994. Evolutionary-developmental change in the growth architecture of fossil rhizomorphic lycopsids: scenarios constructed on cladistic foundations. Biological Reviews 69, 527-598.

DOI 10.1111/j.1469-185X.1994.tb01249.x

BATEMAN, R.M., DiMichele, W.A. \& Willard, D.A. 1992. Experimental cladistic analysis of anatomically preserved arborescent lycopsids from the Carboniferous of Euramerica: an essay on paleobotanical phyllogenetics. Annals of the Missouri Botanical Garden 79, 500-559. DOI $10.2307 / 2399752$

BEK, J. 1998. Spore populations of some plants of groups Lycophyta, Sphenophyta, Pteridophyta and Progymnospermophyta from Carboniferous limnic basins of the Czech Republic. 505 pp. Unpublished Ph.D. thesis, Geological Institute of the Academy of Sciences of the Czech Republic, Prague. [in Czech]

BEK, J. \& OpluŠTIL, S. 1998. Some lycopsid, sphenopsid and pteropsid fructifications and their miospores from the Upper Carboniferous basins of the Bohemian Massif. Palaeontographica B 248, 127-161.

BEK, J. \& OPLUŠTIL, S. 2004. Palaeoecological constraints of some Lepidostrobus cones and their parent plants from the Late Palaeozoic continental basins of the Czech Republic. Review of Palaeobotany and Palynology 131, 49-89. DOI 10.1016/j.revpalbo.2004.02.008

BEK, J. \& OPLUŠTIL, S. 2006. Six rare Lepidostrobus cones from the Pennsylvanian of the Czech Republic and their bearing on the classification of lycospores. Review of Palaeobotany and Palynology 139, 211-226.

DO1 10.1016/j.revpalbo.2006.01.003

BINNEY, E.W. 1870-1875. Observations on the structure of fossil plants found in the Carboniferous strata. 147 pp. Monograph of the Palaeontographical Society, London.
BOCHEŃSKI, T. 1936. Über Sporophyllstände (Blüten) einiger Lepidophyten aus dem produktiven Karbon Polens. Annales de la Société géologique de Pologne 12, 193-240.

BOCHEŃSKI, T. 1939. On the structure of sigillarian cones and the mode of their association with their stems. Prace Geologiczne 7, 1-28.

BRACK, S.D. 1970. On a new structurally preserved arborescent lycopsid fructification from the Lower Pennsylvanian of North America. American Journal of Botany 57, 317-330. DOI $10.2307 / 2485310$

BRACK-HANES, S.D. \& THOMAS, B.A. 1983. A re-examination of Lepidostrobus Brongniart. Botanical Journal of the Linnean Society 86, 125-133.

DO1 10.1111/j.1095-8339.1983.tb00720.x

BRONGNIART, A. 1828. Historie des végétaux fossiles, ou recherches botaniques et géologiques sur les végétaux renfermés dans les diverses couches du globe. 1 - 488 pp.; 2- 72 pp. G. Dufour \& E. d'Ocagne, Paris.

CARPENTIER, A. 1933. Sur quelques épis de lépidodnedrées du Westphalien du basin de Valenciennes. Annales de la Société scientifique de Bruxelles 53B, 133-137.

CARRUTHERS, W. 1865. On an undescribed cone from the Carboniferous beds of Aidrie, Lanarkshire. Geological Magazine 2, 433-440.

Chaloner, W.G. 1953a. On the megaspores of four species of Lepidostrobus. Annals of Botany 17, 264-273.

CHALONER, W.G. 1953b. On the megaspores of Sigillaria. The Annals and Magazine of Natural History 12, 881-897.

Chaloner, W.G. 1967. Lycophyta, 435-802. In Boureau, E. (ed.) Traité de Paléobotanique, II, Bryophyta, Psilophyta, Lycophyta. Masson, Paris.

CHALONER, W.G. 1986. Reassembling the whole fossil plant, and naming it, 67-78. In SPICER, R.A. \& THOMAS, B.A. (eds) Systematic and taxonomic approaches in palaeobotany. Clarendon Press, Oxford.

CHALONER, W.G. 1999. Taxonomic and nomenclatural alternatives, 179-183. In JONES, T.P. \& ROWE, N.P. (eds) Fossil plants and spores: modern techniques. Geological Society, London.

Chapman, G.R. 1999. Coal Resources Map of Britain. British Geological Survey, NERC and The Coal Authority, Bristol.

Cleal, C.J., Dimitrova, T.K. \& Zodrow, E.L. 2003. Macrofloral and palynological criteria for recognising the Westphalian-Stephanian boundary. Newsletters on Stratigraphy 39, 181-208.

Cleal, C.J. \& SHUTE, C.H. 2007. The effect of drying on epidermal cell parameters preserved on plant cuticles. Acta Palaeobotanica 47, 315-326.

Courvoisier, J.M. \& PHILliPS, T.L. 1975. Correlation of spores from Pennsylvanian coal-ball fructifications with dispersed spores. Micropaleontology 21, 45-49.

DOI $10.2307 / 1485154$

CROOKALL, R. 1964. Fossil Plants of the Carboniferous Rocks of Great Britain. Memoirs of the Geol. Survey of Great Britain. Palaeontology 4(3), 217-354.

CrookAll, R. 1966. Fossil Plants of the Carboniferous Rocks of 
Great Britain. Memoirs of the Geol. Survey of Great Britain. Palaeontology 4(4), 355-572.

DetTMAnN, M.E. 1963. Upper Mesozoic microfloras from south-eastern Australia. Proceedings of the Royal Society of Victoria 77, 1-148.

DRÁBEK, K. 1967. Spóry ze šištic Lepidodender. 56 pp. Master thesis, Facilty of Sciences, Charles University, Prague. [in Czech]

Feistmantel, O. 1871. Steinkohlen von Kralup in Böhmen. Abhandlungen der Königl. Böhmischen Gesselschaft der Wissenschaften 6(5).

FELIX, C.J. 1954. Some American arborescent lycopod fructifications. Annals of the Missouri Botanical Garden 41, 351-394. DOI $10.2307 / 2394684$

FenG, B.C. \& Rothwell, G.W. 1989. Microsporangiate cones of Mazocarpon bensonii (Lycopsida) from the Upper Pennsylvanian of the Appalachian Basin. Review of Palaeobotany and Palynology 57, 289-297. DOI 10.1016/0034-6667(89)90026-2

FENG, Z., WANG, J. \& BEK, J. 2008. Nudasporestrobus ningxicus gen. et sp. nov., a novel sigillarian megasporangiate cone from the Bashkirian (Early Pennsylvanian) of Ningxia, northwestern China. Review of Palaeobotany and Palynology 149, 150-162. DOI 10.1016/j.revpalbo.2007.11.003

Forey, P., ForTey, R., KenRICK, P. \& SMith, A.B. 2004. Taxonomy and fossils: a critical appraisal. Philosophical Transactions of the Royal Society of London 359, 639-653. DOI 10.1098/rstb.2003.1453

GEINITZ, H.B. 1855. Die Versteinerungen der Steinkohlenformation in Sachsen. 61 pp. Wilhelm Engelmann, Leipzig.

GEINITZ, E. 1973. Versteinerungen aus dem Brandschiefer der unteren Dyas von Weissig bei Pillnitz in Sachsen. Neues Jahrbuch für Mineralogie, Geologie und Paläontologie, 691-704.

HAGEMANN, H.W. 1966. Sporen aus köhlig erhaltenen Lepidophytenzapfen des Westfals. Fortschritte in der Geologie von Rheinland und Westphalen 13(1), 317-388.

KIDSTON, R. 1893/4. On Lepidophloios and on British species of the genus. Transactions of the Royal Society of Edinburgh $37(3)$.

KIDSTON, R. 1888. On the fossil flora of the Radstock series of the Sommerset and Bristol coal fields, Ayrshire (Upper coal measures). Transactions of the Royal Society of Edinburgh 33(2).

KIDSTON, R. 1889. Additional notes on some British Carboniferous Lycopods. The Annals and Magazine of Natural History 6(4), 1-60.

KIDSTON, R. 1891. On the fossil flora of the Staffordshire coal fields II. Transactions of the Royal Society of Edinburgh 36.

KIDSTON, R. 1893. On the fossil flora of the South Wales coal field and the relationship of its strata to the Sommerset and Bristol coal fields. Transactions of the Royal Society of Edinburgh 37(3).

LEISMAN, G.A. \& RIVERS, R.L. 1974. On the reproductive organs of Lepidodendron serratum Felix. C.R. Rendu Septième Congrès International de Stratigraphie et Géologie du Carbonifére, Krefeld, Band 3, 351-365.
LINDLEY, J. \& HUTTON, W. 1831-1837. The fossil flora of Great Britain, or figures and descriptions of the vegetable remains found in a fossil state in the country. I - 223 pp.; II - 208 pp.; III - 208 pp. James Rigdway \& Sons, London.

Mathews, G.B. 1940. New lepidostrobi from central Unites States. Botanical Gazette 102, 26-49.

DOI $10.1086 / 334933$

MEYEN, S.V. 1987. Fundamentals of Palaeobotany. 432 pp. Chapman \& Hall, London.

McNeill, J., Barrie, F.R., Burdet, H.M., Demoulin, V., HAWKSWORTH, D.L., MARHOLD, K., NiCOLSON, D.H., Prado, J., Silva, P.C., Skog, J.E., Wiersema, J.H. \& TURLAND, N.J. 2006. International code of botanical nomenclature (Vienna Code) adopted by the Seventeenth International Botanical Congress, Vienna, Austria, July 2005. 568 pp. A.R.G. Ganter Königstein.

MOORE, L. R. 1946. On the spores of some Carboniferous plants, their development. Quarterly Journal of the Geological Society of London 102, 251-298.

NĚMEJC, F. 1947. The Lepidodendraceae of the coaldistricts of Central Bohemia. Sborník Národního muzea v Praze, R̆ada B 7(2), 45-87.

NĚMEJC, F. 1954. Taxonomical studies on the strobili of the Lepidodendraceae of the coal district of Central Bohemia.

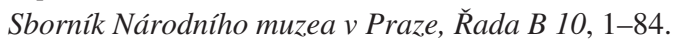

OPLUŠTIL, S. \& CLEAL, C.J. 2007. A comparative analysis of some Late Carboniferous basins of Variscan Europe. Geological Magazine 144, 417-448.

DOI $10.1017 / \mathrm{S} 0016756807003330$

PARKINSON, J. 1804. Organic remains of a former world. Vol. I, The Vegetable Kingdom. i-xii pp. Sherwood, Neely \& Jones, London.

PhILliPS, T.L. \& DiMichelE, W.A. 1992. Comparative ecology and life-history biology of arborescent lycopsids in late Carboniferous swamps of Euramerica. Annals of the Missouri Botanical Garden 79, 560-588. DOI 10.2307/2399753

PIGG, K.B. 1983. The morphology and reproductive biology of the sigillarian cone Mazocarpon. Botanical Gazette 144, 600-613. DO] $10.1086 / 337417$

Potonié, R. \& KREMP, G. 1954. Die Gattungen der Palaözoischen Sporae dispersae und ihre Stratigraphie. Geologisches Jahrbuch 69, 111-193.

Potonié, R. \& KREMP, G. 1955. Die Sporae dispersae des Ruhrkarbons ihre Morphographie und Stratigraphie mit Ausblicken auf Arten anderer Gebiete und Zeitabschnitte. Teil I. Palaeontographica, Abteilung B 98, 1-136.

REMY, W. \& RETTSCHLAG, W. 1954. Beiträge zur Kenntnis einiger Paläozoischer Fruktifikationen. Geologie 3, 582-586.

SCHIMPER, W.P. 1870. Traité de paléontologie végétale. Tome II. Paris.

SCHOPF, J.M. 1941. Contribution to Pennsylvanian paleobotany. Mazocarpon oedipternum sp. nov. and sigillarian relationships. Illinois State Geological Survey, Report of Investigation $75,1-40$.

SCOTT, D.H. 1909. Studies in Fossil Botany, 2. edition. 552 pp. A. \& C. Black Ltd., London. 
SEN, J. 1958. Notes on the spores of four Carboniferous lycopods. Micropalaleontology 4(2), 159-164. DOI $10.2307 / 1484301$

SMith, A.H.V. \& BUTTERWORTH, M.A. 1967. Miospores in the coal seams of the Carboniferous of Great Britain. Special Papers in Palaeontology 1, 1-324.

SCHUMACKER-LAMBRY, J. 1966. Étude d'un cône de Lepidodendraceae du houiller Belge: Achlamydocarpon belgicum gen. et sp. nov. Mémoires de l'Académie royale des sciences, des lettres et des beaux-arts de Belgique 17, 5-27.

TAYLOR, T.N. \& EGGERT, D. 1968. Petrified plants from the Upper Mississippian of North America II. Lepidostrobus fayettevillense sp. nov. American Journal of Botany 55, 306-313. DOI $10.2307 / 2440416$

THOMAS, B.A. 1965. Some studies on Carboniferous lycopods. Ph.D. thesis, Reading University.

THOMAS, B.A. 1970. A new specimen of Lepidostrobus binneyanus from the Westphalian B of Yorkshire. Pollen et Spores 12, 217-234.

THOMAS, B.A. 1978. Carboniferous Lepidodendraceae and Lepidocarpaceae. The Botanical Review 44(3), 321-364. DOI 10.1007/BF02957853

THOMAS, B.A. 1987. The use of in-situ spores for defining species of dispersed spores. Review of Palaeobotany and Palynology 51, 227-233. DOI 10.1016/0034-6667(87)90032-7

ThomAs, B.A. 1988. The fine structure of the Carboniferous lycophyte microspore Lycospora perforata Bharadwaj and Venkatachala. Pollen et Spores 30, 81-88.

THOMAS, B.A. 2007. Phytogeography of Asturian (Westphalian D) lycophytes throughout the Euramerican belt of coalfields. Geological Magazine 144, 457-463.

\section{DOI $10.1017 /$ S001675680700338X}

THOMAS, B.A. \& BRACK-HANES, S.D. 1984. A new approach to family groupings in the lycophytes. Taxon 33, 247-255. DOI 10.2307/1221165

THOMAS, B.A. \& BRACK-HANES, S.D. 1991. A re-examination of Cantheliophorus Bassler. Neues Jahrbuch für Geologie und Paläontologie, Abhandlungen 183(1/3), 203-215.

ThOMAS, B.A. \& DYTKO, A. 1980. Lepidostrobus haslingdenensis: a new species from the Lancashire Millstone Grit. Geological Journal 15, 137-142.

WILLARD, D.A. 1989a. Source plants for Carboniferous microspores: Lycospora from permineralized Lepidostrobus. American Journal of Botany 76, 820-826. DOI $10.2307 / 2444538$

WILLARD, D.A. 1989b. Lycospora from Carboniferous Lepidostrobus compressions. American Journal of Botany 76, 1429-1440. DOI 10.2307/2444429

WoOD, J.M. 1957. The morphology and relationships of sigillarian fructifications from the Lower Pennsylvanian of Indiana. American Midland Naturalist 58(1), 141-154.

DOI $10.2307 / 2422366$ 